\title{
Occurrence and Distribution of Nitrate and Selected Pesticides in Ground Water in Missouri, 1986-94
}

By Donald H. Wilkison and Randall D. Maley

U.S. GEOLOGICAL SURVEY

Water-Resources Investigations Report 96-4183

Prepared in cooperation with the Missouri Department of Health

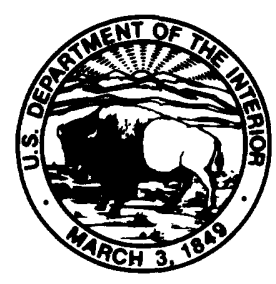




\title{
U.S. DEPARTMENT OF THE INTERIOR \\ BRUCE BABBITT, Secretary
}

\author{
U.S. GEOLOGICAL SURVEY
}

Gordon P. Eaton, Director

For additional information write to:

\section{District Chief}

U.S. Geological Survey

1400 Independence Road

Mail Stop 100

Rolla, Missouri 65401
Copies of this report may be purchased from:

U.S. Geological Survey

Branch of Information Services

Box 25286

Denver, Colorado 80225-0286 


\section{CONTENTS}

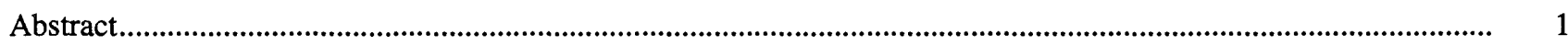

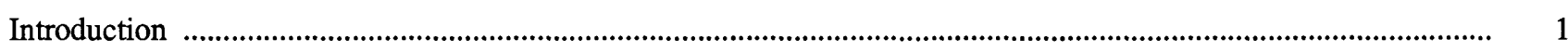

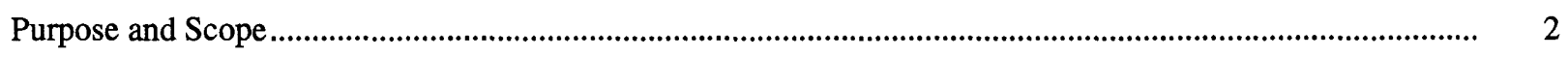

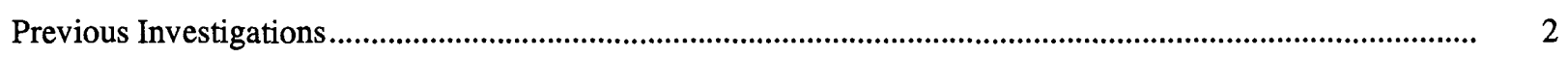

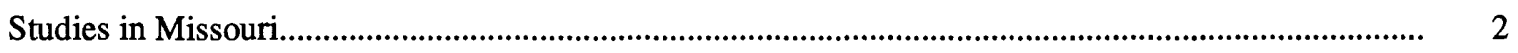

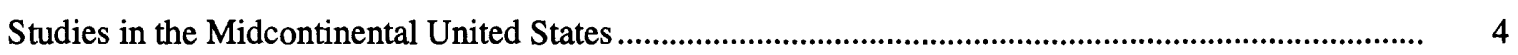

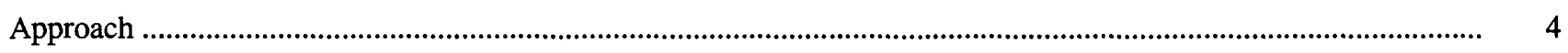

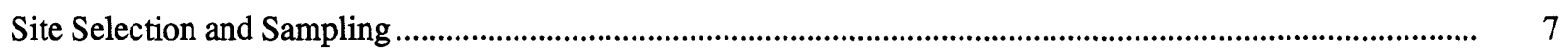

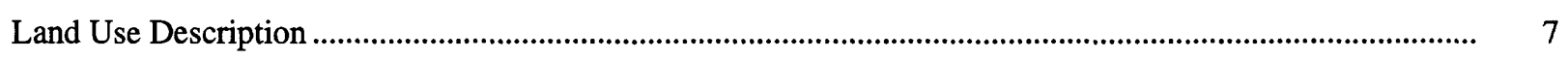

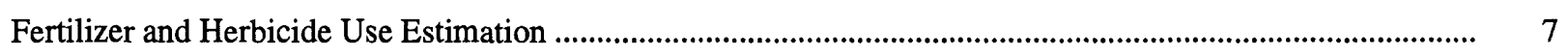

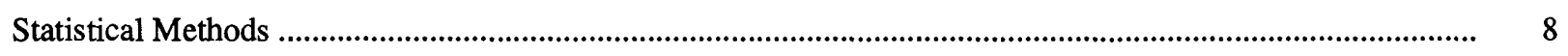

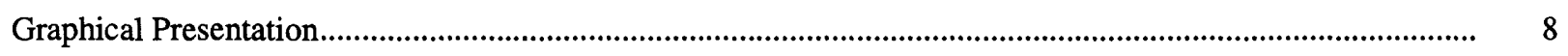

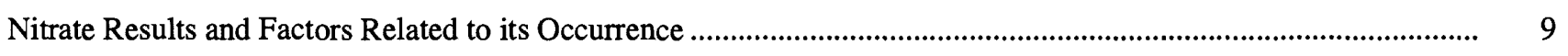

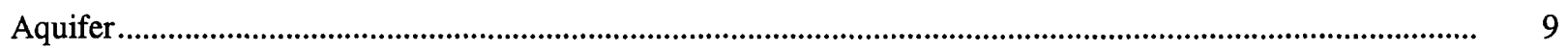

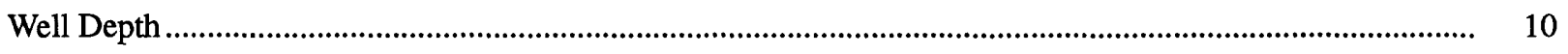

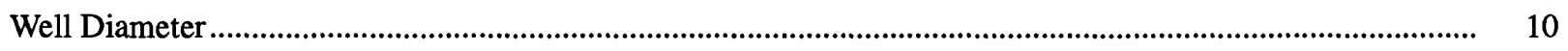

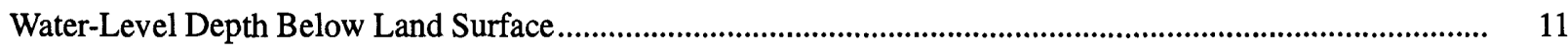

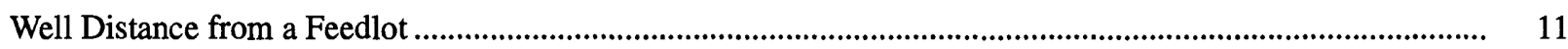

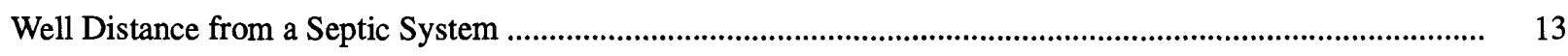

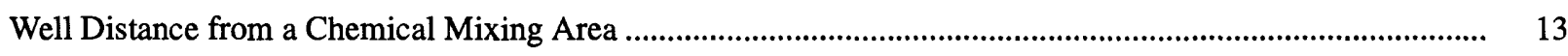

Percentage of Row Crops Within a 0.25-Mile Radius of the Well ............................................................. 13

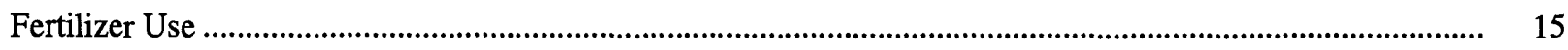

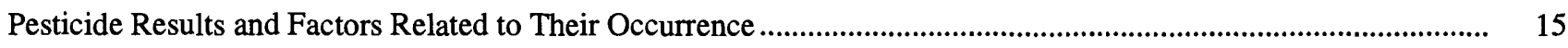

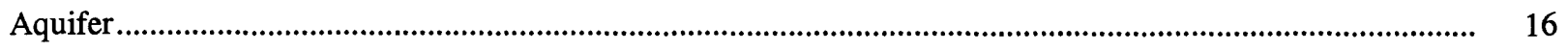

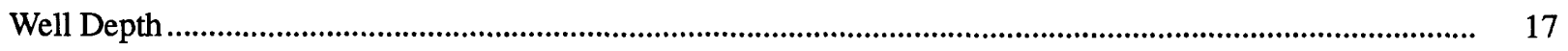

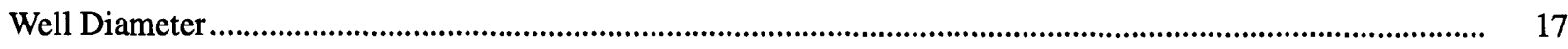

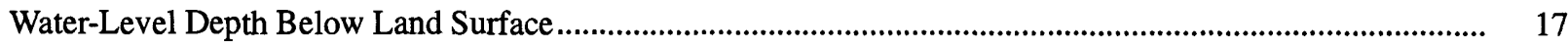

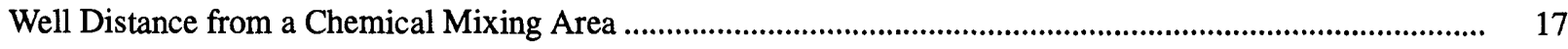

Percentage of Row Crops Within a 0.25-Mile Radius of the Well .................................................................. 19

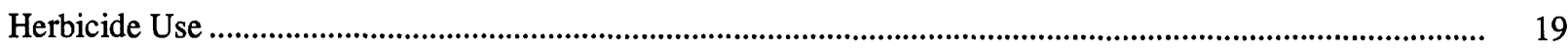

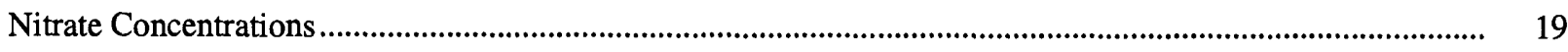

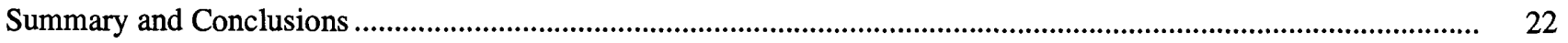

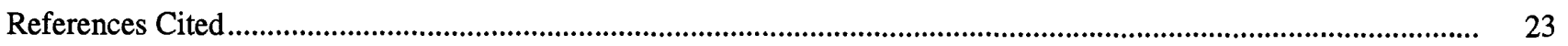




\section{ILLUSTRATIONS}

1-3. Maps showing:

1. Location of study areas and ground-water sampling sites.................................................................. 3

2. Estimated 1990 Missouri fertilizer use .............................................................................................. 5

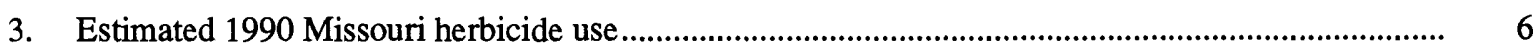

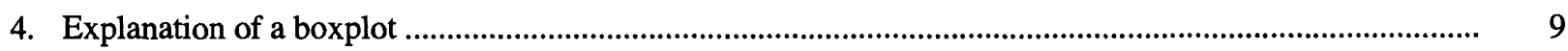

5-14. Boxplots showing:

5. Nitrate concentrations from various aquifers ….......................................................................... 9

6. Nitrate concentrations for various well depths .......................................................................... 10

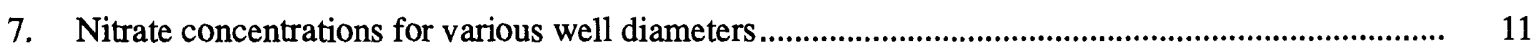

8. Nitrate concentrations for various water-level depths below the land surface ..................................... 12

9. Nitrate concentrations for various well distances from a feedlot ...................................................... 12

10. Nitrate concentrations for various well distances from a septic system .......................................... 13

11. Nitrate concentrations for various well distances from a chemical mixing area................................ 14

12. Nitrate concentrations for various percentages of row crops within a 0.25 -mile radius of a well ...... 14

13. Fertilizer use for various ranges of nitrate concentrations .................................................................. 15

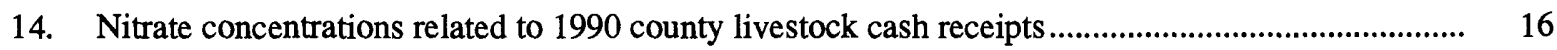

15-20. Graphs showing relation of pesticide detection frequency to:

15. Aquifer.

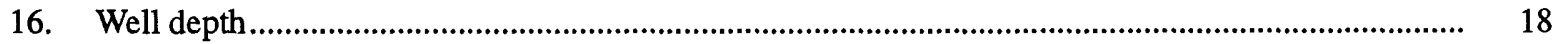

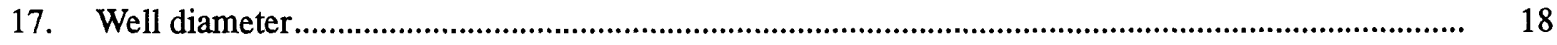

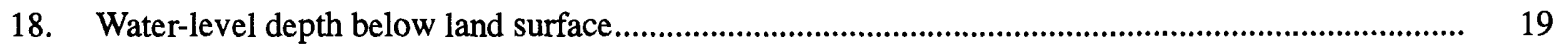

19. Well distance from a chemical mixing area........................................................................................ 20

20. The percentage of row crops within a 0.25 -mile radius of the well ................................................... 20

21. Boxplot showing estimated herbicide use and pesticide detection category ................................................. 21

22. Boxplot showing nitrate concentrations and pesticide detection category ..................................................... 21

\section{TABLES}

1. Summary of selected agricultural chemical studies in the midcontinental United States............................ 29

2. Summary of nitrate concentrations in ground water by study area ........................................................ 30

3. Summary of pesticide detections in ground water by study area ............................................................... 31

4. Median concentrations of nitrate in water samples from various aquifers ................................................. 10 


\title{
Occurrence and Distribution of Nitrate and Selected Pesticides in Ground Water in Missouri, 1986-94
}

\author{
By Donald H. Wilkison ${ }^{1}$ and Randall D. Maley ${ }^{2}$
}

\section{Abstract}

Data from 854 wells and 38 springs in Missouri were analyzed for the occurrence and distribution of nitrate, as nitrogen $\left(\mathrm{NO}_{3}\right)$, and selected pesticides. Sampling sites were located in 81 of the 114 counties in Missouri. Samples were collected between 1986 and 1994 and were obtained primarily from near-surface aquifers. More than 40 percent of the sites were located in counties where at least 25 percent of the land was used for agricultural row-crop production.

Ground water from glacial drift or Pennsylvanian rocks had significantly higher concentrations of nitrate and more frequent pesticide detections than did ground water from alluvial, Mississippian/Springfield Plateau, or Cambrian-Ordovician/Ozark aquifers. Water samples from wells less than 75 feet deep, greater than 6 inches in diameter, and where the water level was within 50 feet of the land surface had significantly higher nitrate concentrations and were more prone to pesticide detections than samples from other wells.

Nitrate was detected with greater frequency and at much higher concentrations than were pesticides. More than 36 percent of wells had $\mathrm{NO}_{3}$ concentrations in excess of 3 milligrams per liter, indicating a possible anthropogenic source of $\mathrm{NO}_{3}$ for many wells. Water samples from 151 wells (17.6 percent) had $\mathrm{NO}_{3}$ concentrations greater than or equal to the Missouri drinking-water-supply criterion of 10 milligrams per liter.

Slightly more than 11 percent of the sites had pesticide concentrations in excess of 0.1 microgram

\footnotetext{
${ }^{1}$ Hydrologist, U.S. Geological Survey, Independence, Missouri.

${ }^{2}$ Environmental Specialist, Missouri Department of Health, Jefferson City, Missouri.
}

per liter. Pesticide concentrations exceeded the maximum contaminant level or health advisory limit for drinking water at 1.9 percent of the sites. Atrazine was the most frequently detected pesticide.

Samples from wells where chemicals were mixed within 100 feet of the well had significantly higher concentrations and more frequent detections of pesticides than samples from other wells. The percentage of row crops within a 0.25 -mile radius of the well was not related to $\mathrm{NO}_{3}$ concentrations or pesticide detection frequency. Nitrate concentrations in ground water were inversely related to estimated fertilizer-use rates. However, herbicide-use rates were not significantly related to pesticide detection frequency.

Nitrate concentrations were significantly higher in samples with pesticide detections than for those without detections. Wells less than 0.25 mile from a feedlot had significantly higher $\mathrm{NO}_{3}$ concentrations than other wells; however, $\mathrm{NO}_{3}$ concentrations were not related to the well distance from a septic system.

\section{INTRODUCTION}

Many Missourians rely on ground water as their sole supply of drinking water. In 1990, there were 336,600 private drinking-water wells in the State. Approximately 783,000 people used these wells as their supply of domestic water (U.S. Department of the Census, 1991). In 1980, domestic-water use accounted for approximately one-third of all groundwater use in the State (Marikos and Skelton, 1983).

Average annual crop fertilizer use in Missouri was 786 million pounds between 1986 and 1992 (University of Missouri, 1993). In 1989, more than 8 million pounds of pesticides were applied to crops in Missouri to improve crop yields (Smith and Fairchild, 1990). Because of the potential for agricultural chemicals to affect ground-water resources, the U.S. Geo- 
logical Survey (USGS) and the Missouri Department of Health (MDOH) examined data collected between 1986 and 1994 on the occurrence and distribution of agricultural chemicals in ground water in Missouri. The objectives of this study were to compile existing data on the occurrence and distribution of agricultural chemicals in ground water and to determine statistical relations between the occurrence of agricultural chemicals and selected land-use patterns.

\section{Purpose and Scope}

This report describes the occurrence and distribution of nitrate, as nitrogen, hereafter referred to as $\mathrm{NO}_{3}$, and selected pesticides in ground water. The report is based on samples from 854 domestic wells and 38 springs in Missouri and provides a summary of the associated water-quality data. Analyses of how these distributions are affected by the factors of hydrogeology, well construction, agricultural practices, and land-use patterns are presented. The report focuses primarily on areas of the State that are considered to be the most susceptible to agricultural chemical contamination.

\section{Previous Investigations}

Previous investigations addressing agricultural chemicals in ground water in Missouri include studies conducted solely within Missouri and regional studies that examined large geographic areas in the midcontinental United States. The data for these investigations were compiled and supplemented with data collected in other studies to provide the basis for this report. Most of the data were gathered during a series of cooperative USGS and MDOH investigations.

\section{Studies in Missouri}

Cooperative studies by the USGS and MDOH began in 1986 and continued through 1992. The studies documented the occurrence and distribution of $\mathrm{NO}_{3}$ and selected pesticides in ground water in the areas of the State considered the most susceptible to contamination. Six regions of the State were sampled (fig. 1). These areas were selected because they were areas of intense agricultural production that rely primarily on shallow sources of ground water for water supplies. The methods, sampling details, and analytical results for these studies are given in a series of reports (Mesko and Carlson, 1988; Ziegler and others, 1993, 1994; Wilkison and Maley, 1994).
During a 1986-87 study in the southeast lowlands, 74 domestic, 25 irrigation wells, and 25 publicwater-supply wells were sampled for $\mathrm{NO}_{3}$ and selected pesticides (Mesko and Carlson, 1988). Concentrations of $\mathrm{NO}_{3}$ exceeded $10 \mathrm{mg} / \mathrm{L}$ (milligrams per liter) in $\mathbf{1 7 . 5}$ percent of the sites. Concentrations of one or more pesticides were detected at 13.2 percent of the sites.

Ninety-five domestic wells in two reaches of the Missouri River alluvium were sampled in 1988 and 1989 for $\mathrm{NO}_{3}$ and selected pesticides (Ziegler and others, 1993). Samples from 12.6 percent of the sites had $\mathrm{NO}_{3}$ concentrations in excess of $10 \mathrm{mg} / \mathrm{L}$, and concentrations of one or more pesticides were detected at 11.6 percent of the sites.

Ground water from west-central Missouri was sampled at 123 sites in 1990 and 1991. Concentrations of $\mathrm{NO}_{3}$ exceeded $10 \mathrm{mg} / \mathrm{L}$ at 19.5 percent of the sites (Ziegler and others, 1994). The isotopic signature of the $\mathrm{NO}_{3}\left(\delta^{15} \mathrm{~N}\right)$ at these sites indicated that animal wastes were the predominant sources of the nitrate concentrations (Wilkison, 1993). Samples from 23.6 percent of the sites had detectable concentrations of one or more pesticides.

In 1991, 130 domestic wells were sampled in northwestern Missouri for $\mathrm{NO}_{3}$ and herbicides (Wilkison and Maley, 1994). Concentrations of $\mathrm{NO}_{3}$ exceeded $10 \mathrm{mg} / \mathrm{L}$ in samples from 23.8 percent of the sites. Concentrations of one or more herbicides were detected in 14.6 percent of the samples.

Water samples were collected from 147 domestic wells in northeastern Missouri in 1992 and analyzed for $\mathrm{NO}_{3}$ and herbicides (Wilkison and Maley, 1994). Nineteen percent of the samples from wells had $\mathrm{NO}_{3}$ concentrations in excess of $10 \mathrm{mg} / \mathrm{L}$ and 12.9 percent had detectable concentrations of one or more herbicides.

Sievers and Fulhage (1992) sampled 201 rural domestic wells in selected counties in Missouri (fig. 1) between 1987 and 1989. Nitrate concentrations, which exceeded $10 \mathrm{mg} / \mathrm{L}$ in 22 percent of the samples, were determined to be related to well depth, well construction methods, and well location. Forty-three percent of the wells sampled had at least one pesticide detection. The pesticides included 11 herbicides and 8 insecticides. More than 95 percent of the samples with concentrations greater than or equal to $1 \mu \mathrm{g} / \mathrm{L}$ (microgram per liter) were from wells along and north of the Missouri River. Pesticide detections correlated most 


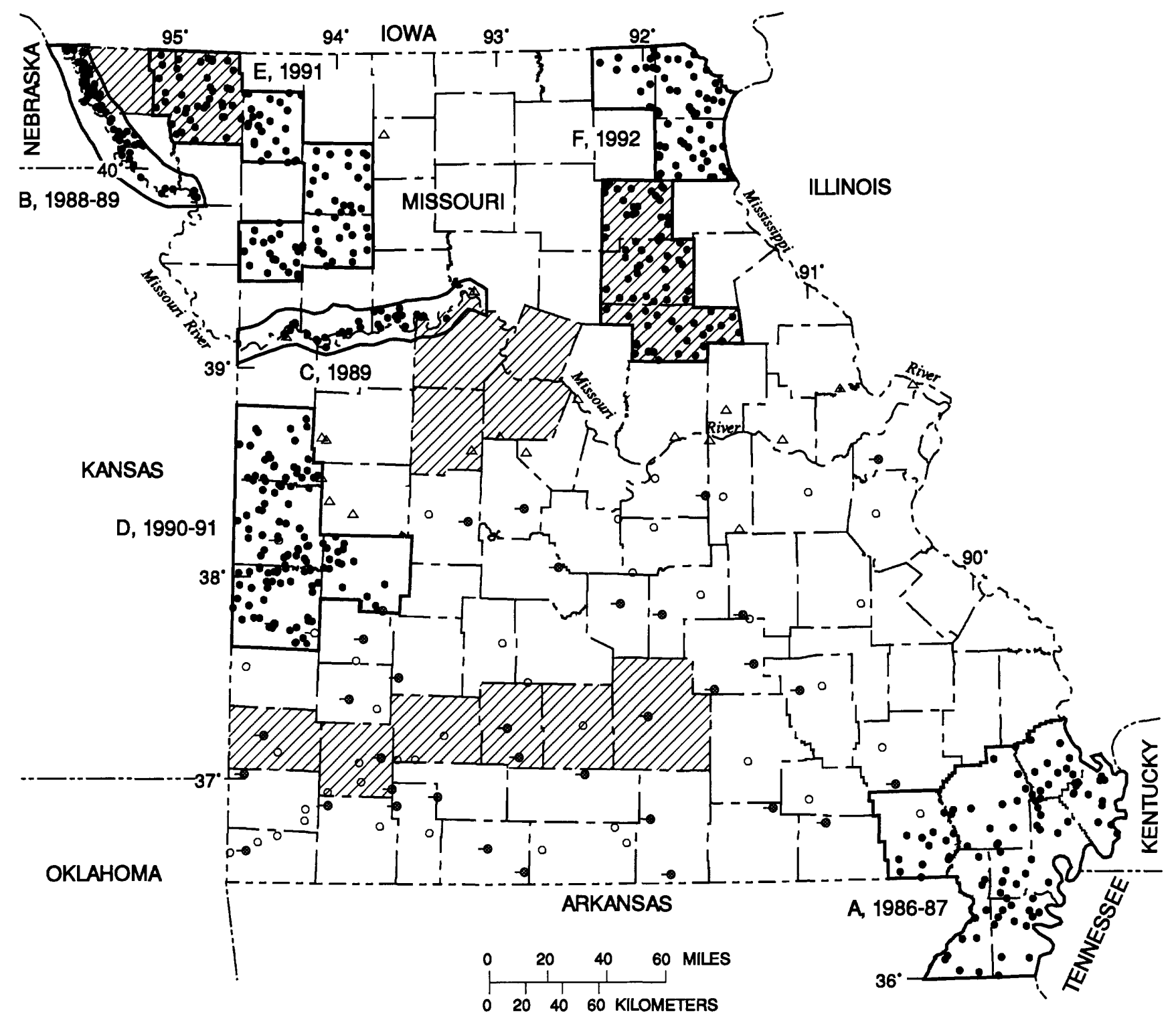

EXPLANATION

\begin{tabular}{|c|c|}
\hline & $\begin{array}{l}\text { U.S. GEOLOGICAL SURVEYMISSOURI } \\
\text { DEPARTMENT OF HEALTH STUDY AREA, } \\
\text { SAMPLE YEAR }\end{array}$ \\
\hline A & Southeast lowlands (Mesko and Carlson, 1988) \\
\hline & Missouri River alluvium (Ziegler and others, 1993) \\
\hline B & Northwestem reach \\
\hline C & West-central reach \\
\hline D & West-central Missouri (Ziegler and others, 1994) \\
\hline$E$ & Northwestem Missouri (Wiikison and Maley, 1994) \\
\hline $\mathbf{F}$ & Northeastem Missouri (Wilkison and Maley, 1994) \\
\hline
\end{tabular}

VD COUNTY SAMPLED (Sievers and Fulhage, 1992)

WE丩 SITE

- U.S. Geological Survey/Missouri Department Of Health

- Ozark Plateaus National Water-Quality Assessment study

$\Delta \quad$ Midcontinent Herbicide Initiative

\section{SPRING SITE}

$\multimap \quad$ U.S. Geological Survey/Missouri Department Of Health

- Ozark Plateaus National Water-Quality Assessment study

Figure 1. Location of study areas and ground-water sampling sites. 
strongly with well depth (greatest detection frequencies at shallow depths).

A survey of all Missouri public and community drinking-water supplies (PDWS) conducted in 1993 and 1994 determined only three detectable concentrations of pesticides from suppliers that use ground water as the source (Darrell Osterhoudt, Missouri Public Drinking Water Program, Missouri Department of Natural Resources, oral commun., 1995). The PDWS wells often are screened at much deeper intervals than domestic wells because of the yields needed to supply large quantities of potable water.

\section{Studies in the Midcontinental United States}

Wells throughout parts of the midcontinental United States were sampled in 1991, 1992, and 1993 (Kolpin and others, 1993, 1994, 1995; Kolpin and Thurman, 1995) to determine hydrogeologic, spatial, and seasonal distribution of $\mathrm{NO}_{3}$, selected pesticides, and pesticide metabolites. This study is referred to as the Midcontinent Herbicide Initiative (MCHI) and focused on near-surface aquifers [within $50 \mathrm{ft}$ (feet) of the land surface]. During 1991, 28.4 percent of the sites had detectable concentrations of one or more pesticides or an atrazine metabolite. Twenty-four wells were sampled in Missouri as part of the MCHI (fig. 1). None of the sites had $\mathrm{NO}_{3}$ concentrations greater than $10 \mathrm{mg} / \mathrm{L}$. Three sites (12.5 percent) had detectable pesticide concentrations. Atrazine was detected at two sites. During the 1992 study, which focused on a larger group of pesticides, 62 percent of the sampled wells had detectable pesticide concentrations. Twenty-seven different pesticides were detected. The pesticide detection frequency was related to the depth to the aquifer, irrigation within $5 \mathrm{mi}$ (miles) of the well, proximity of the well to streams, and analytical detection limit. Wells sampled in 1993 were used to study the possible effects of flooding in the upper Mississippi River Basin on agricultural chemicals in ground water. Water samples from the Missouri River alluvial aquifer had a four-fold increase in the pesticide detection frequency after the flood of 1993.

The Ozark Plateaus study unit of the National Water-Quality Assessment (NAWQA) Program includes a large part of southern Missouri. Samples were collected from 39 shallow domestic wells and 35 springs in Missouri during 1993 and 1994 for $\mathrm{NO}_{3}$ and pesticide concentrations (fig. 1). Concentrations of $\mathrm{NO}_{3}$ and pesticides did not exceed health-based limits at any of the sites (Nowell and Resek, 1994). Pesti- cides were detected at 17 sites ( 23 percent), with atrazine as the most frequently detected pesticide (10 sites, 13.5 percent). Prometon was detected at seven sites (9.5 percent; Adamski and Pugh, 1996). The pesticide detections were significantly related to aquifer type and spring discharge. The NAWQA sampling methods for pesticide analysis involved using techniques that allow for the quantification of pesticides at concentrations of $0.001 \mu \mathrm{g} / \mathrm{L}$. These quantification levels are an order of magnitude less than the detection limits used in previous studies within Missouri.

Numerous statewide studies throughout the midcontinental United States have described the occurrence and distribution of agricultural chemicals in ground water. A summary of selected studies is included to show the variability of sampling methods and results from state-to-state, as well as within the states (table 1, at the back of this report). Other studies have examined the occurrence and distribution of $\mathrm{NO}_{3}$ and herbicides in surface water (Battaglin and others, 1993; Goolsby and Battaglin, 1993; Mueller and others, 1993), the persistence of herbicides in reservoirs (Goolsby and others, 1993a), and herbicide transport in precipitation (Nations and Hallberg, 1992; Goolsby and others, 1993b).

\section{APPROACH}

Water samples were collected in areas of Missouri that are expected to have the greatest potential effect from agricultural practices. These include areas that have the highest estimated rates of fertilizer and herbicide use (figs. 2, 3) and that principally use shallow ground-water sources for drinking water.

Samples from wells and springs used for this study were located in 81 of the 114 counties in Missouri. These counties represent the most intensive agricultural crop production areas in Missouri. More than 40 percent of the sites were located in counties with at least 25 percent of the land in the county used for row-crop production. In some counties, more than one-half of the county acreage was in row crops.

Most water samples considered in the study were collected from wells and springs completed in near-surface aquifers. Aquifer names in Missouri are not uniform throughout the State, but have been developed somewhat independently for separate areas that coincide with major geohydrologic investigations. Aquifers north of the Missouri River were defined and named in Imes (1985) and Young (1992) as part of the Northern Midwest Regional Aquifer-System Analysis. 


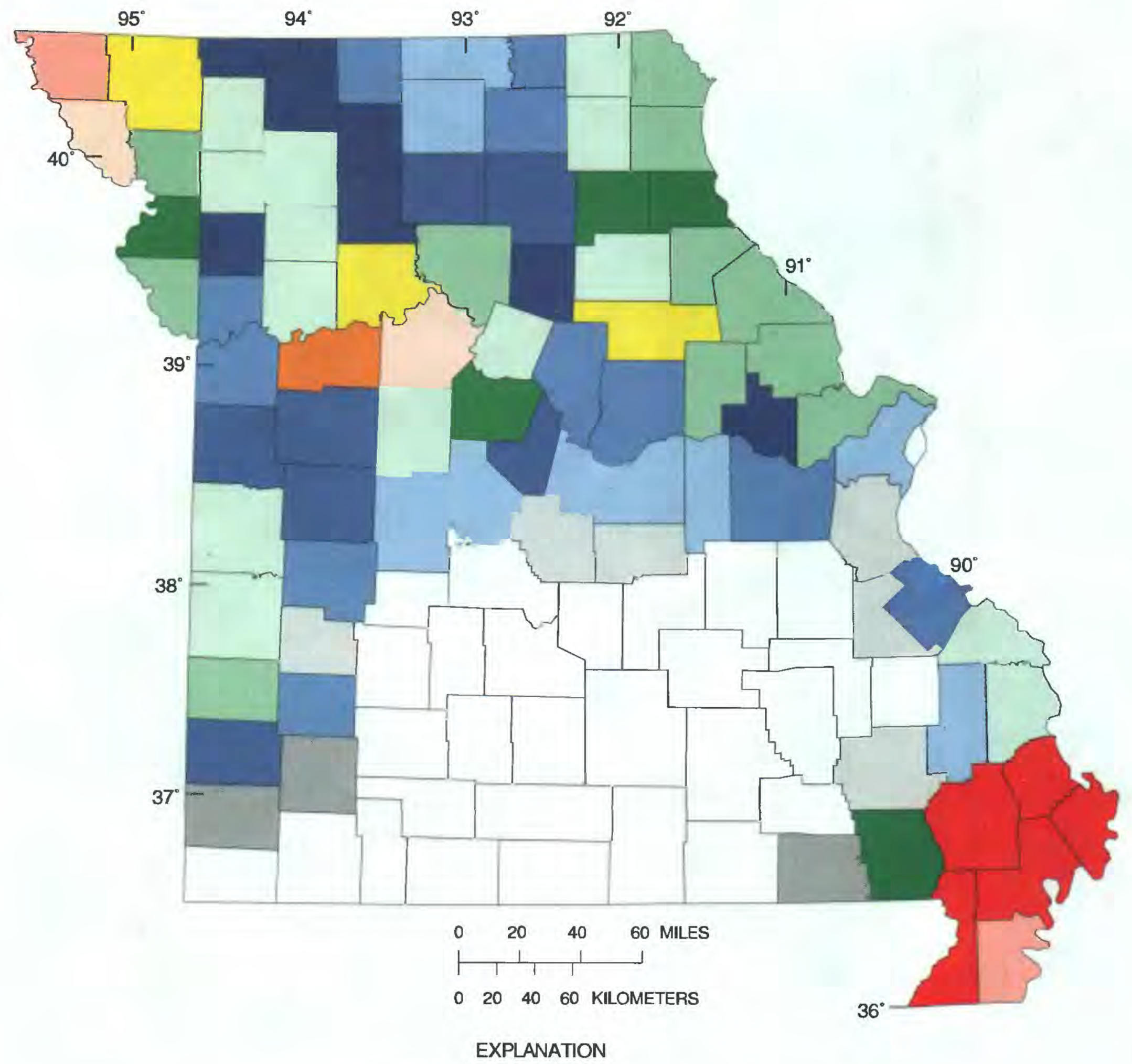

FERTILIZER USE-In pounds of nitrogen per square mile

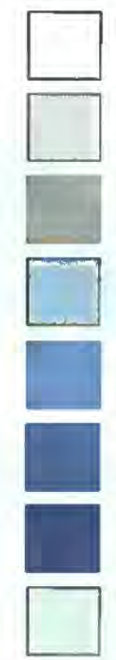

Less than 500

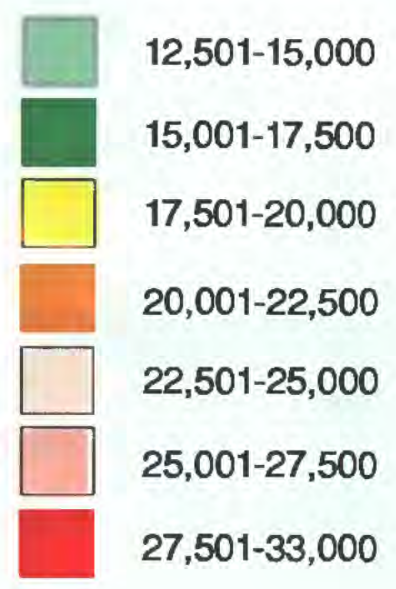

$501-1,000$

$1,001-2,000$

$2,001-4,000$

$4,001-6,000$

$6,001-8,000$

$8,001-10,000$

$10,001-12,500$

Figure 2. Estimated 1990 Missouri fertilizer use (data from Pauley, 1991; U.S. Department of Agriculture, 1994). 


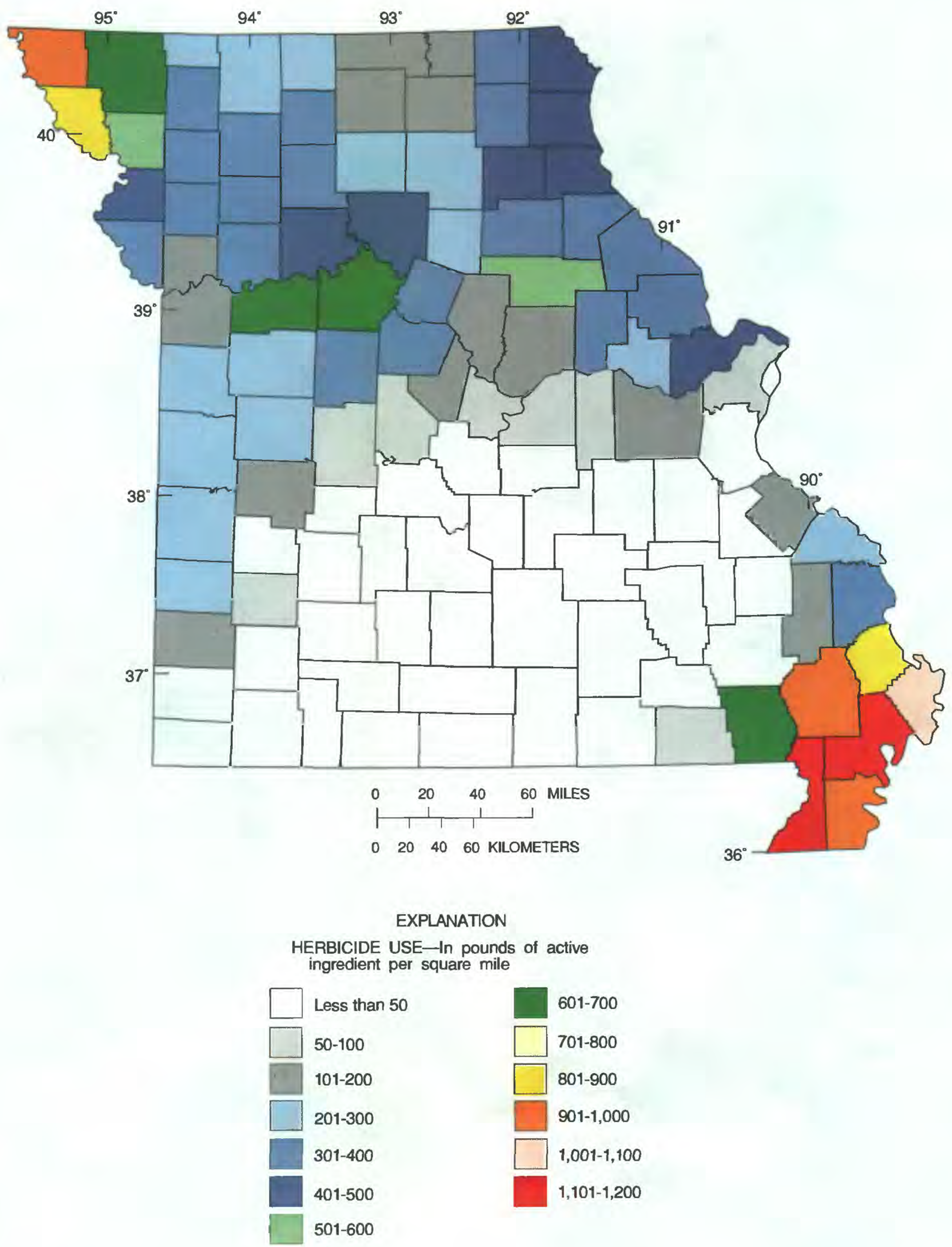

Figure 3. Estimated 1990 Missouri herbicide use (data from Smith and Fairchild, 1990; Pauley, 1991). 
Aquifers south of the Missouri River, excluding the southeast lowlands, were defined and named in Imes and Emmett (1994) as part of the Central Midwest Regional Aquifer-System Analysis. Aquifers in the southeast lowlands of Missouri were defined and named in Brahana and Mesko (1988) as part of the Gulf Coast Regional Aquifer-System Analysis. Alluvial aquifers, such as the Missouri and Mississippi River alluvial aquifers, are named for the river from which they are formed. Because these studies were conducted by different teams of hydrologists and included different geohydrologic conditions and formation lithologies in multi-state settings, aquifer nomenclature is not entirely consistent among the studies. However, there are similarities in the aquifer definitions and terminology. This report uses combined terminology from Imes (1985), Brahana and Mesko (1988), and Imes and Emmett (1994).

The term glacial drift will be used herein to identify the geohydrologic unit from which water is collected from wells completed in glacial drift and loess deposits. Glacial drift may be classified as a confining unit or an extremely poor aquifer. The term Pennsylvanian rocks will be used to describe the geohydrologic unit from which water is collected from wells completed in Pennsylvanian rocks in northern Missouri or the Western Interior Plains confining system in west-central Missouri. Where rocks of Pennsylvanian age are sandstone or fractured limestone, small well yields are possible. The Mississippian aquifer of northern Missouri is nearly equivalent to the Springfield Plateau aquifer of southern Missouri. In this report, the term Mississippian/Springfield Plateau aquifer will be used to identify the approximately equivalent units and will include Meremecian Series rocks of Mississippian age in extreme northeastern Missouri not included in the original definition of the Mississippian aquifer. The Cambrian-Ordovician aquifer of northern Missouri is nearly equivalent to the Ozark aquifer of southern Missouri. In this report, the term Cambrian-Ordovician/Ozark aquifer will be used to identify the approximately equivalent units. The St. Francis aquifer is a shallow aquifer in southeastern Missouri, but the equivalent unit north of the Missouri River is too deeply buried to be of interest in this study. Water samples from the southeast lowlands are from the Mississippi River alluvial aquifer. Because chemical analyses for water samples from various parts of the State are combined for statistical analysis in this report, the analyses can include samples from different aquifers.

\section{Site Selection and Sampling}

Samples from domestic wells were the focus of this study although samples from 38 springs also were used, either because they were used to supply domestic-drinking water to residents in the area or they represented shallow ground water in an area where few domestic wells were present. Wells and springs considered for this study (fig. 1) were distributed geographically by county and source of water. Data were available from 854 wells and 38 springs.

Descriptions of the selection, sampling methods, analytical methods, and quality-assurance procedures for sites sampled by the USGS are described in a series of reports (Kolpin and Burkart, 1991; Ziegler and others, 1993, 1994; Wilkison and Maley, 1994; Adamski and Pugh, 1996). Selection, sampling, analytical, and quality-assurance criteria for the remaining sites are detailed in Sievers and Fulhage (1992).

\section{Land Use Description}

Selected land-use data were obtained at 428 sites through questionnaires and interviews with land and well owners and onsite observations. Land-use data were not collected before 1991 because sampling methods did not include this component. Land-use data were summarized for three radial distances from the well-less than $100 \mathrm{ft}, 100 \mathrm{ft}$ to $0.25 \mathrm{mi}$, and greater than $0.25 \mathrm{mi}$. Percentages of land use within a 0.25 -mi radius of the well were estimated using intervals of 25 percent. Land-use data are reported in a series of reports (Kolpin and others, 1993; Ziegler and others, 1993, 1994; Wilkison and Maley, 1994).

\section{Fertilizer and Herbicide Use Estimation}

Estimated rates of fertilizer and herbicide use were calculated by county for 1990 based on crop production and fertilizer- and herbicide-use statistics for the seven major crops grown in Missouri (Pauley, 1993). These crops, in order of decreasing production value, are soybeans, corn, hay, wheat, cotton, sorghum, and rice.

The rates of estimated fertilizer use by county (fig. 2) refer to the pounds of nitrogen (N) applied per square mile. These rates were calculated by multiplying the amount of acreage within each county planted 
in each crop in 1990 by the average amount of $\mathrm{N}$ applied to each crop (Pauley, 1991; U.S. Department of Agriculture, 1994). These $\mathrm{N}$ amounts were totaled by county, and the total $\mathrm{N}$ applied within the county was divided by the area of the county to determine the rate of $\mathrm{N}$ applied per square mile.

In 1990, herbicides accounted for more than 92 percent of all pesticides applied in Missouri. Because most wells were analyzed only for selected herbicides, this study examined the relation between the occurrence of pesticides and the estimated rate of herbicide use by county. The rates of estimated herbicide use by county (fig. 3) refer to pounds of active herbicide ingredient applied per square mile. These rates were calculated by multiplying the amount of acreage within each county planted in each major crop in 1990 by the average amount of active herbicide ingredient applied to each crop (Smith and Fairchild, 1990; Pauley, 1991). These herbicide amounts were totaled by county, and the total amount of herbicides applied within the county was divided by the area of the county to determine the rate of herbicides applied per square mile.

Highest rates of fertilizer and herbicide use by county occurred in the southeast lowlands and in counties adjacent to the Missouri River. These areas coincide with the major agricultural areas of the State. The lowest rates of fertilizer and herbicide use by county were in the south-central part of the State, sometimes referred to as the Ozark Plateaus.

\section{Statistical Methods}

Nonparametric statistical methods were used to analyze the data because water-quality data generally are not normally distributed and the data often contain values less than the detection or reporting limit (censored data). Data in this report had these characteristics.

The use of nonparametric statistical methods is appropriate because these methods are not unduly affected by extreme data values (outliers) and because ranks of the data are used instead of the actual concentration of the water-quality constituents. A significance level $(\alpha)$ of 0.05 was used for all statistical tests in this study. At this significance level, there is a 1 in 20 chance that the test reported a significant difference where none actually existed. Often, the attained significance level ( $p$-value) from the test was much lower. The lower the $p$-value, the greater the statistical certainty of the test. A p-value of 0.001 indicates a 1 in
1,000 chance that the test reported a significant difference where none actually existed.

The nonparametric statistical methods included the Kruskal-Wallis test, multiple comparison t-tests on the data ranks, and contingency tables (Helsel and Hirsch, 1992). The Kruskal-Wallis test is an analysis of variance on ranks of data that tests for differences in the central tendency, or medians, of two or more groups. When the Kruskal-Wallis tests indicated a significant difference at the 0.05 level, a t-test on the ranks (Tukey's W) was performed on each paired group to evaluate which groups were statistically different from one another. Data for each factor were analyzed by comparing the ranks of data within categories. Contingency tables were used to measure the statistical significance of factors grouped by herbicide detections or nondetections.

Statistical analyses were performed on the first set of samples collected after the spring planting period, if more than one set of samples was collected during a given year. If a well or spring was sampled repeatedly during the study, the most recent data were used.

Statistical analysis of pesticide data was done based on the presence, or absence, of detectable pesticide concentrations because most of the sites had concentrations less than the minimum reporting limit. Because the analytical detection limit for pesticides varied among sample sets, only concentrations that exceeded $0.1 \mu \mathrm{g} / \mathrm{L}$ were treated as a pesticide detection. Previous research has shown that shifts in pesticide analytical limits can significantly affect the frequency of detections (Kolpin and others, 1995). Because the number of pesticides analyzed varied among samplings, statistical analysis was performed only for the pesticides analyzed in all samples. These pesticides, all of which are herbicides, are alachlor, atrazine, cyanazine, metolachlor, metribuzin, prometon, simazine, and trifluralin. Summary tables of $\mathrm{NO}_{3}$ and pesticides analyzed by study area, including concentration ranges and analytical detection limits, are at the back of this report (tables 2,3).

\section{Graphical Presentation}

Boxplots are used in this report to display the relations between continuous and categorical variables. Boxplots provide a concise visual summary of essential data characteristics and a way to visually compare multiple data sets. Boxplots (fig. 4) show the median of the data (central tendency), the variation in 
the data, the skewness of the data, and the presence or absence of outliers within the data set.

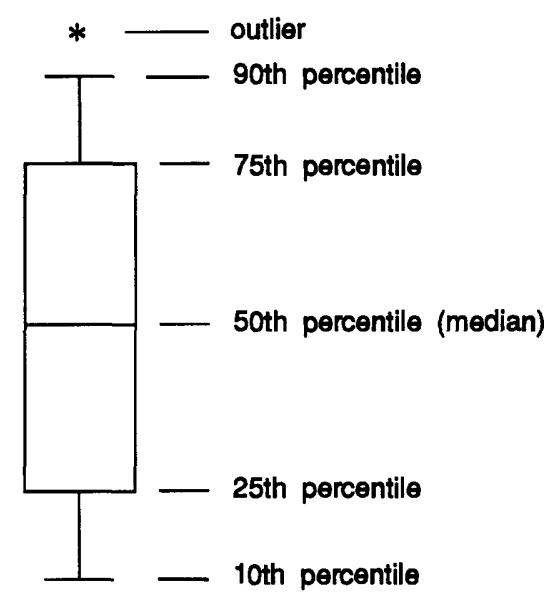

Figure 4. Explanation of a boxplot.

\section{NITRATE RESULTS AND FACTORS RELATED TO ITS OCCURRENCE}

Nitrate, as nitrogen, analyses from 818 wells and 38 springs were used in this study. Nitrate concentrations in water samples were detected at or above the $0.05 \mathrm{mg} / \mathrm{L}$ reporting limit at 605 sites ( 70.7 percent). The frequency of $\mathrm{NO}_{3}$ detections was high because $\mathrm{NO}_{3}$ can originate from a variety of natural and human sources. Nitrate concentrations ranged from less than
0.05 to $96 \mathrm{mg} / \mathrm{L}$. The median $\mathrm{NO}_{3}$ concentration in all samples was $1.1 \mathrm{mg} / \mathrm{L}$.

Madison and Brunett (1985) suggested a value of $3 \mathrm{mg} / \mathrm{L}$ as a possible division between natural and anthropogenic (human-related) sources of $\mathrm{NO}_{3}$ in ground water. Water samples from 313 sites ( 36.6 percent) had $\mathrm{NO}_{3}$ concentrations greater than or equal to $3 \mathrm{mg} / \mathrm{L}$. Water samples from 151 sites (17.6 percent) had $\mathrm{NO}_{3}$ concentrations greater than or equal to the Missouri drinking-water-supply criterion of $10 \mathrm{mg} / \mathrm{L}$ (Missouri Department of Natural Resources, 1992).

Nitrate data were examined for statistical relations among hydrogeologic, well, agricultural-practice, and land-use data. Water samples from shallow, large-diameter wells completed in glacial drift or Pennsylvanian rocks and from wells where the water table was within $50 \mathrm{ft}$ of the land surface, within 0.25 mi of a feedlot, or within $100 \mathrm{ft}$ of a chemical mixing area were more likely to have elevated $\mathrm{NO}_{3}$ concentrations. Elevated $\mathrm{NO}_{3}$ concentrations were not significantly related to the percentage of row crops within a 0.25 -mi radius from the well and were inversely related to county-wide fertilizer usage.

\section{Aquifer}

Nitrate concentrations in water samples from wells were significantly related to the aquifer (Kruskal-Wallis test; $\mathrm{p}<0.001$; fig. 5). Median $\mathrm{NO}_{3}$ concentrations in water samples from various aquifers

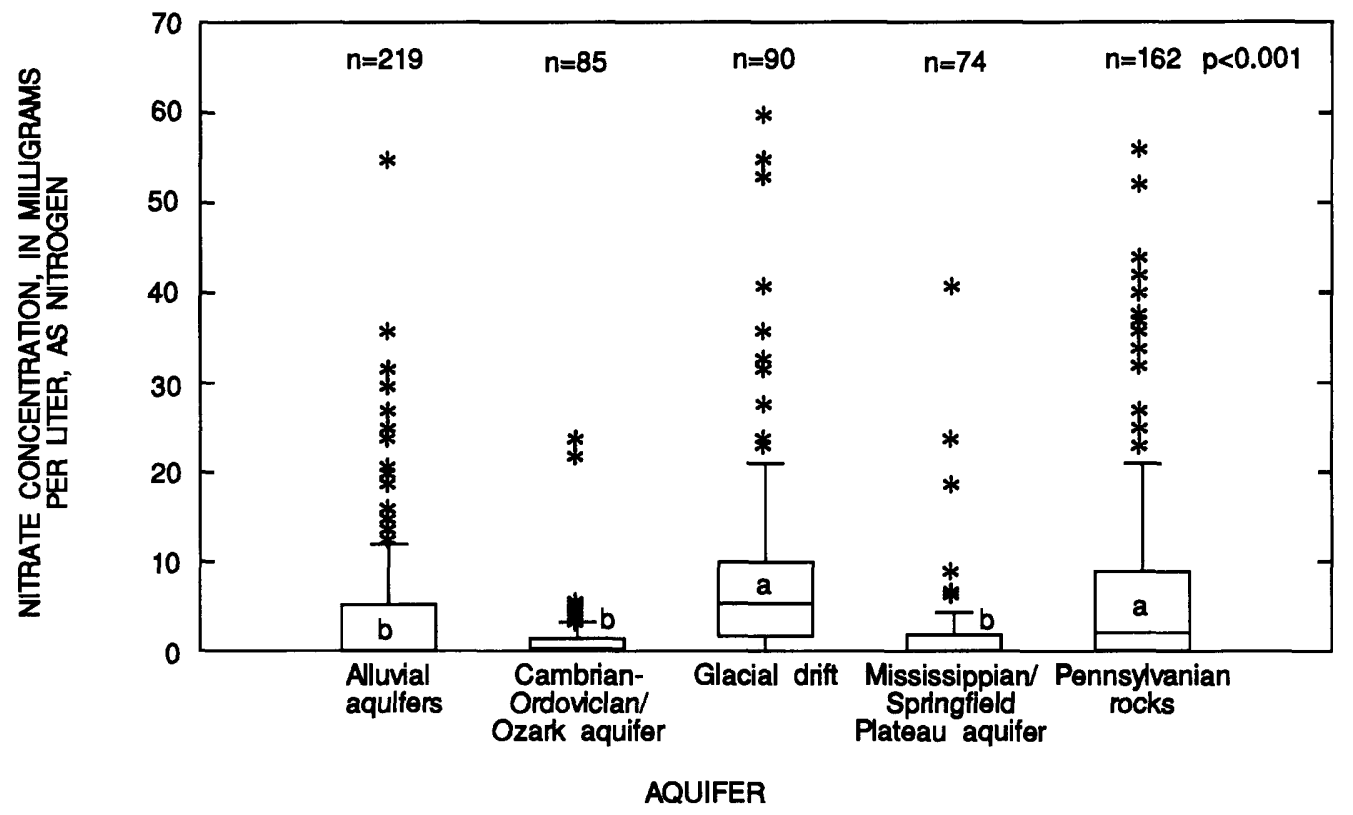

Figure 5. Nitrate concentrations from various aquifers [boxplots with different letters indicate that a significant difference exists between categories (Tukey's test; $\alpha=0.05$ ); $p$, attained significance level from Kruskal-Wallis test; $n$, number of samples]. 
within Missouri are listed in table 4. Multiple comparisons indicate that significant differences in median $\mathrm{NO}_{3}$ concentrations exist between wells completed in alluvial, Mississippian/Springfield Plateau, or Cambrian-Ordovician/Ozark aquifers and wells completed in glacial drift and Pennsylvanian rocks (Tukey's test; $\alpha=0.05$ ). Because of the hydrogeologic setting of these aquifers within the State, domestic wells completed in alluvial, glacial drift, and Pennsylvanian rocks tend to be shallower than those completed in Mississippian/Springfield Plateau and CambrianOrdovician/Ozark aquifers.

Table 4. Median concentrations of nitrate in water samples from various aquifers

[ $\mathrm{NO}_{3}$, nitrate, as nitrogen; $\mathrm{mg} / \mathrm{L}$, milligrams per liter]

\begin{tabular}{lc}
\hline \multicolumn{1}{c}{ Aqulfer } & $\begin{array}{c}\text { Medlan } \mathrm{NO}_{3} \\
\text { concentratlon } \\
\text { (mg/L) }\end{array}$ \\
\hline Alluvial & 0.09 \\
Cambrian-Ordovician/Ozark aquifer & .30 \\
Glacial drift & 5.3 \\
Mississippian/Springfield Plateau aquifer & .05 \\
Pennsylvanian rocks & 2.05 \\
\hline
\end{tabular}

\section{Well Depth}

Nitrate concentrations were significantly related to well depth (Kruskal-Wallis test; $p<0.001$; fig. 6). Water samples from wells less than $75 \mathrm{ft}$ deep had significantly higher $\mathrm{NO}_{3}$ concentrations than those samples from wells that were deeper than $75 \mathrm{ft}$ (Tukey's test; $\alpha=0.05$ ). Water from wells completed in shallow aquifers is more susceptible to contamination because of shorter flow paths and less time for degradation and denitrification to occur. Median $\mathrm{NO}_{3}$ concentrations were highest $(3.9 \mathrm{mg} / \mathrm{L})$ in samples from wells less than $25 \mathrm{ft}$ deep and consistently declined for increasing well depth (fig. 6). The median $\mathrm{NO}_{3}$ concentration was $2.4 \mathrm{mg} / \mathrm{L}$ for samples from wells 25 to $50 \mathrm{ft}$ deep, $1.8 \mathrm{mg} / \mathrm{L}$ for wells 50.1 to $75 \mathrm{ft}$ deep, and $0.05 \mathrm{mg} / \mathrm{L}$ (the analytical detection limit) for wells deeper than 75 ft.

\section{Well Diameter}

Nitrate concentrations were significantly related to well diameter (Kruskal-Wallis test; $\mathrm{p}<0.001$; fig. 7). Water samples from wells with diameters less than or equal to 6 in. (inches) had significantly lower concentrations of $\mathrm{NO}_{3}$ than did those samples from wells with diameters greater than 6 in. (Tukey's test;

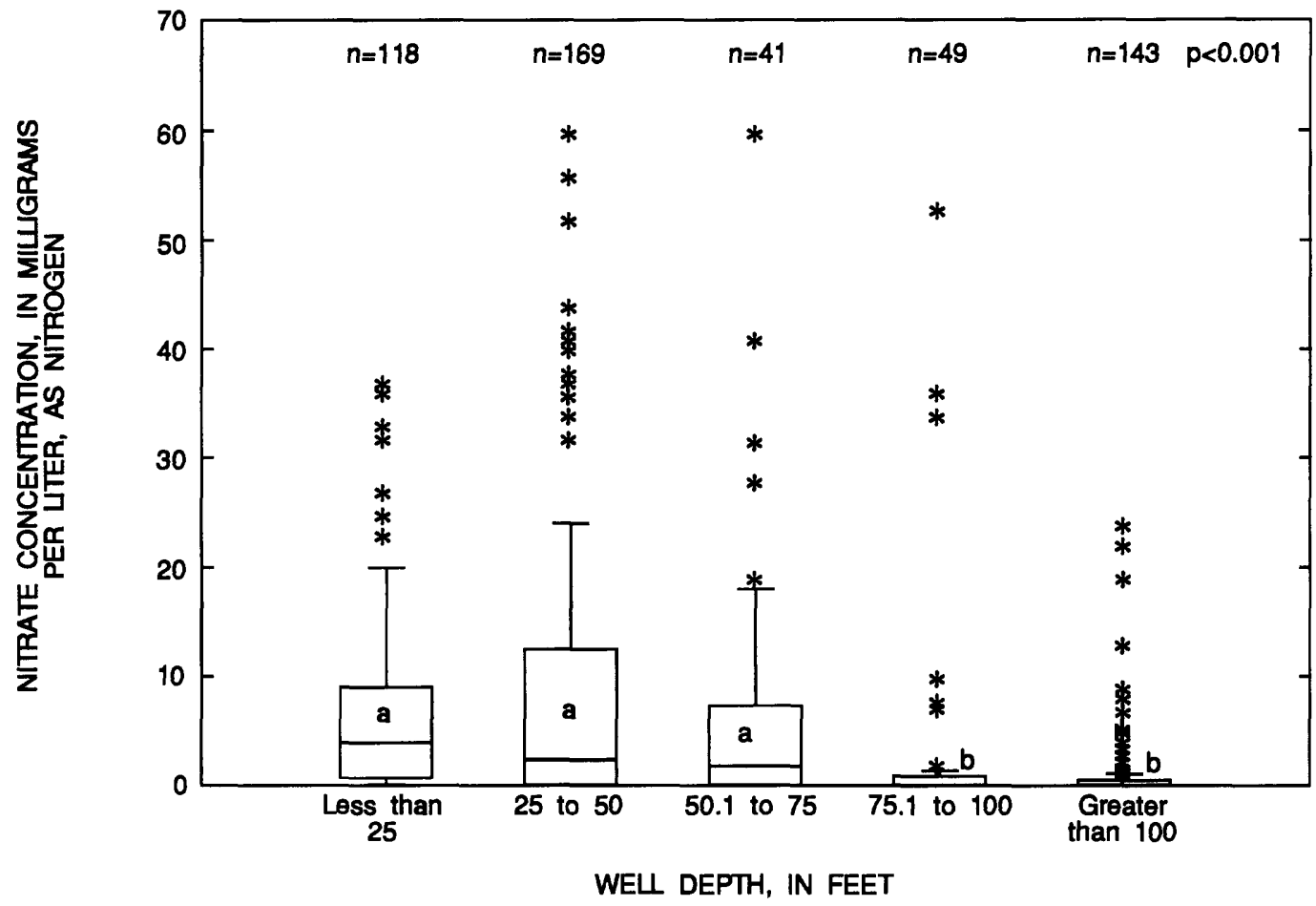

Figure 6. Nitrate concentrations for various well depths [boxplots with different letters indicate that a significant difference exists between categories (Tukey's test; $\alpha=0.05$ ); $p$, attained significance level from Kruskal-Wallis test; $n$, number of samples]. 


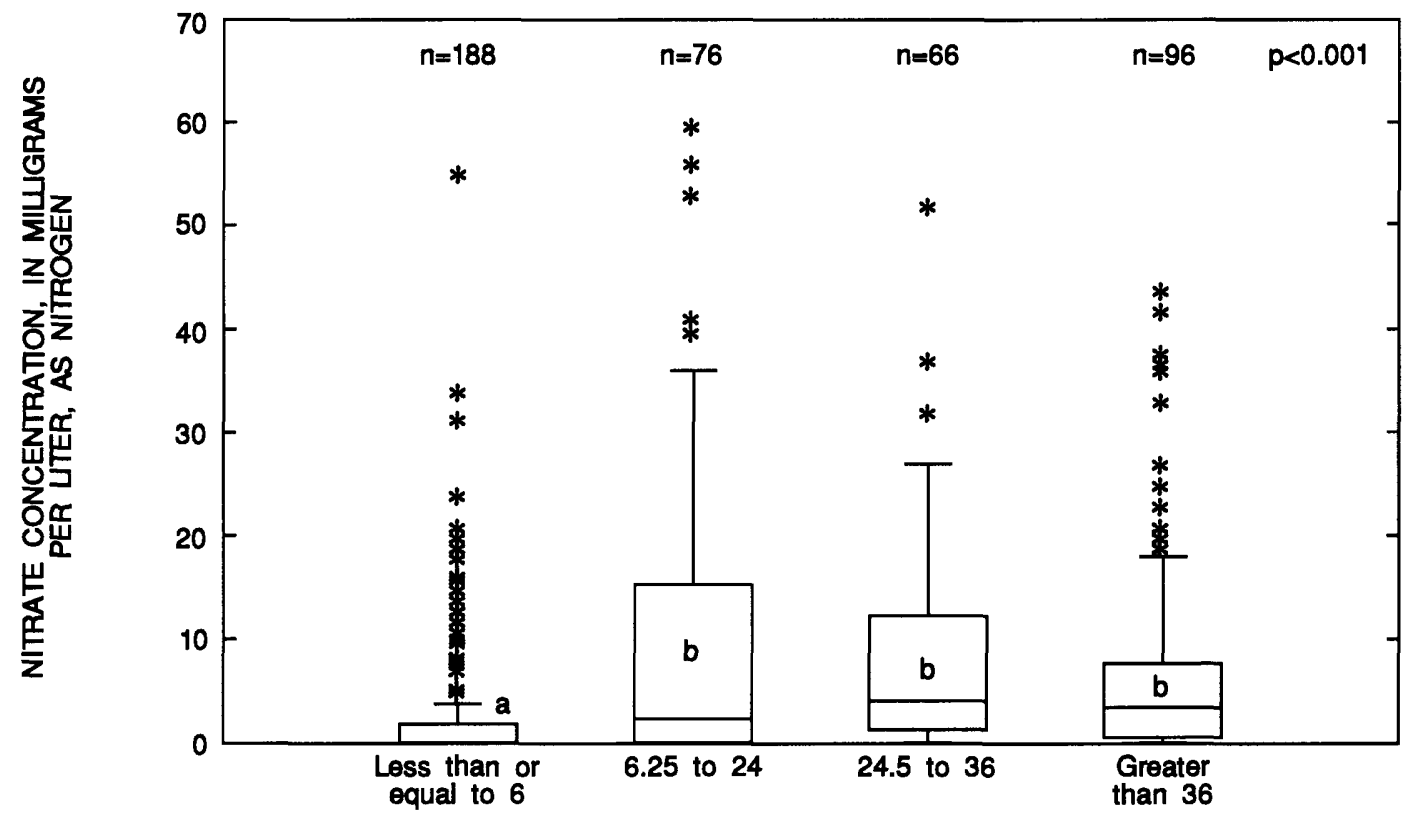

WEL DIAMETER, IN INCHES

Figure 7. Nitrate concentrations for various well diameters [boxplots with different letters indicate that a significant difference exists between categones (Tukey's test; $\alpha=0.05$ ); $p$, attained significance level from Kruskal-Wallis test; $n$, number of samples].

$\alpha=0.05)$. This relation probably exists because wells with diameters 6 in. or less were most likely to be completed in either alluvial, Mississippian/Springfield Plateau, or Cambrian-Ordovician/Ozark aquifers. Wells completed in glacial drift and Pennsylvanian rocks were significantly larger in diameter (Tukey's test; $\alpha=0.05$ ) and many are poorly cased or constructed. Median $\mathrm{NO}_{3}$ concentration in samples from wells 6 in. or less in diameter was $0.05 \mathrm{mg} / \mathrm{L}, 6.25$ to 24 in. in diameter was $2.35 \mathrm{mg} / \mathrm{L}, 24.5$ to 36 in. in diameter was $4.1 \mathrm{mg} / \mathrm{L}$, and greater than $36 \mathrm{in}$. in diameter was $3.45 \mathrm{mg} / \mathrm{L}$ (fig. 7).

\section{Water-Level Depth Below Land Surface}

Nitrate concentrations were significantly related to the water-level depth below the land surface (Kruskal-Wallis test; $\mathrm{p}<0.001$; fig. 8). Water samples from wells in which the water level was less than $50 \mathrm{ft}$ from the land surface had significantly higher $\mathrm{NO}_{3}$ concentrations than samples from wells with water levels deeper than $50 \mathrm{ft}$ below the land surface (Tukey's test; $\alpha=0.05$ ). The median $\mathrm{NO}_{3}$ concentration in samples from wells was $2.1 \mathrm{mg} / \mathrm{L}$ where the water level was less than $10 \mathrm{ft}$ below land surface, 4.3 $\mathrm{mg} / \mathrm{L}$ where it was 10 to $25 \mathrm{ft}$ below land surface, 4.0 $\mathrm{mg} / \mathrm{L}$ where it was 25.1 to $50 \mathrm{ft}$ below land surface,
$0.31 \mathrm{mg} / \mathrm{L}$ where it was 50.1 to $100 \mathrm{ft}$ below land surface, and $0.14 \mathrm{mg} / \mathrm{L}$ where it was deeper than $100 \mathrm{ft}$ below the land surface. Depth to water generally is an indicator of susceptibility of the aquifer to contamination from surface applications of agricultural chemicals. An extremely shallow water table-less than 10 $\mathrm{ft}-$ can be favorable to lower $\mathrm{NO}_{3}$ concentrations, especially in areas with poorly drained soils that often have low dissolved oxygen concentrations. Where these conditions occur, ammonia, and not $\mathrm{NO}_{3}$, tends to be the dominant $\mathrm{N}$ species in the ground water.

\section{Well Distance from a Feedlot}

Nitrate concentrations were significantly related to the distance of a well from a feedlot (Kruskal-Wallis test; $p<0.001$; fig. 9). A feedlot was defined as any present, or historical, confined animal enclosure. Water samples from wells with a feedlot less than 0.25 mi away had significantly higher $\mathrm{NO}_{3}$ concentrations than samples from wells with a feedlot more than 0.25 mi away (Tukey's test; $\alpha=0.05$ ). The highest median concentration of $\mathrm{NO}_{3}(3.7 \mathrm{mg} / \mathrm{L})$ was detected in samples from wells located within $100 \mathrm{ft}$ of a feedlot; samples from wells located between $100 \mathrm{ft}$ and $0.25 \mathrm{mi}$ from a feedlot had only a slightly less median $\mathrm{NO}_{3}$ concentration $(3.5 \mathrm{mg} / \mathrm{L})$. Samples from wells that 


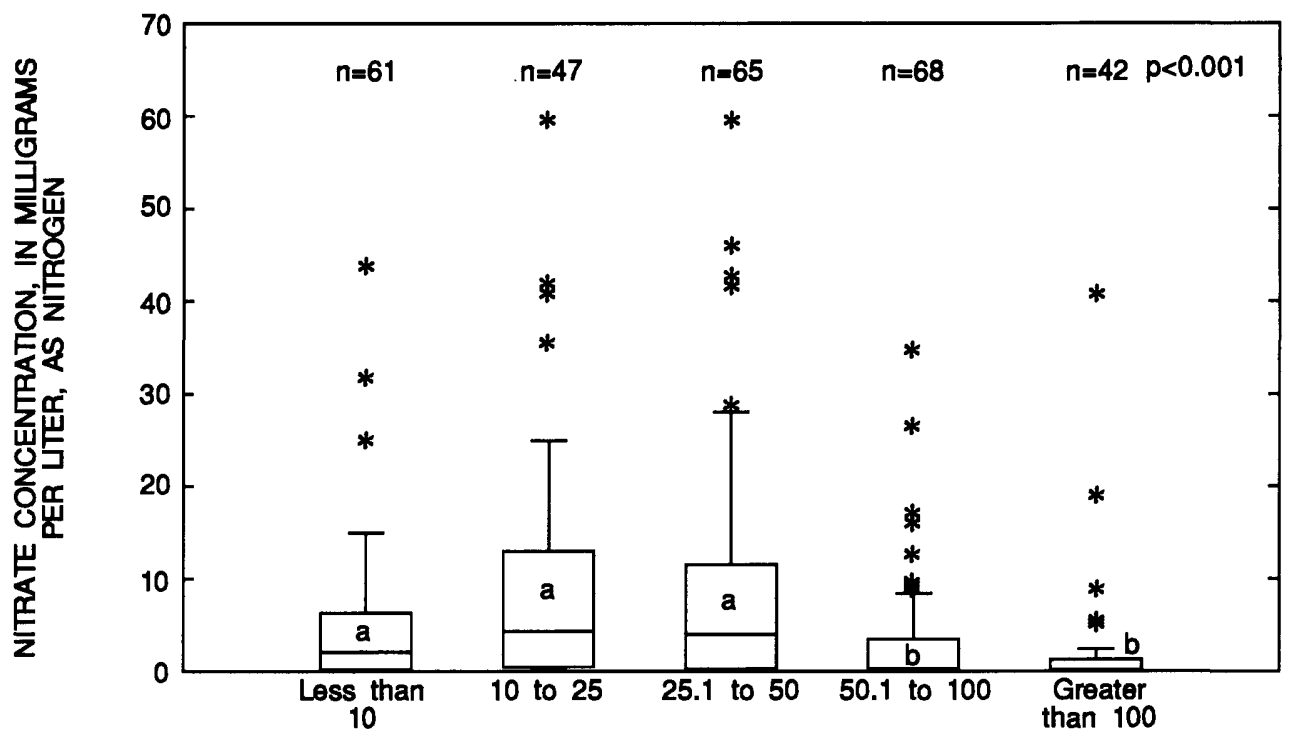

WATER-LEVEL DEPTH BELOW LAND SURFACE, IN FEET

Figure 8. Nitrate concentrations for various water-level depths below the land surface [boxplots with different letters indicate that a significant difference exists between categories (Tukey's test; $\alpha=0.05$ ); $p$, attained significance level from Kruskal-Wallis test; $n$, number of samples].

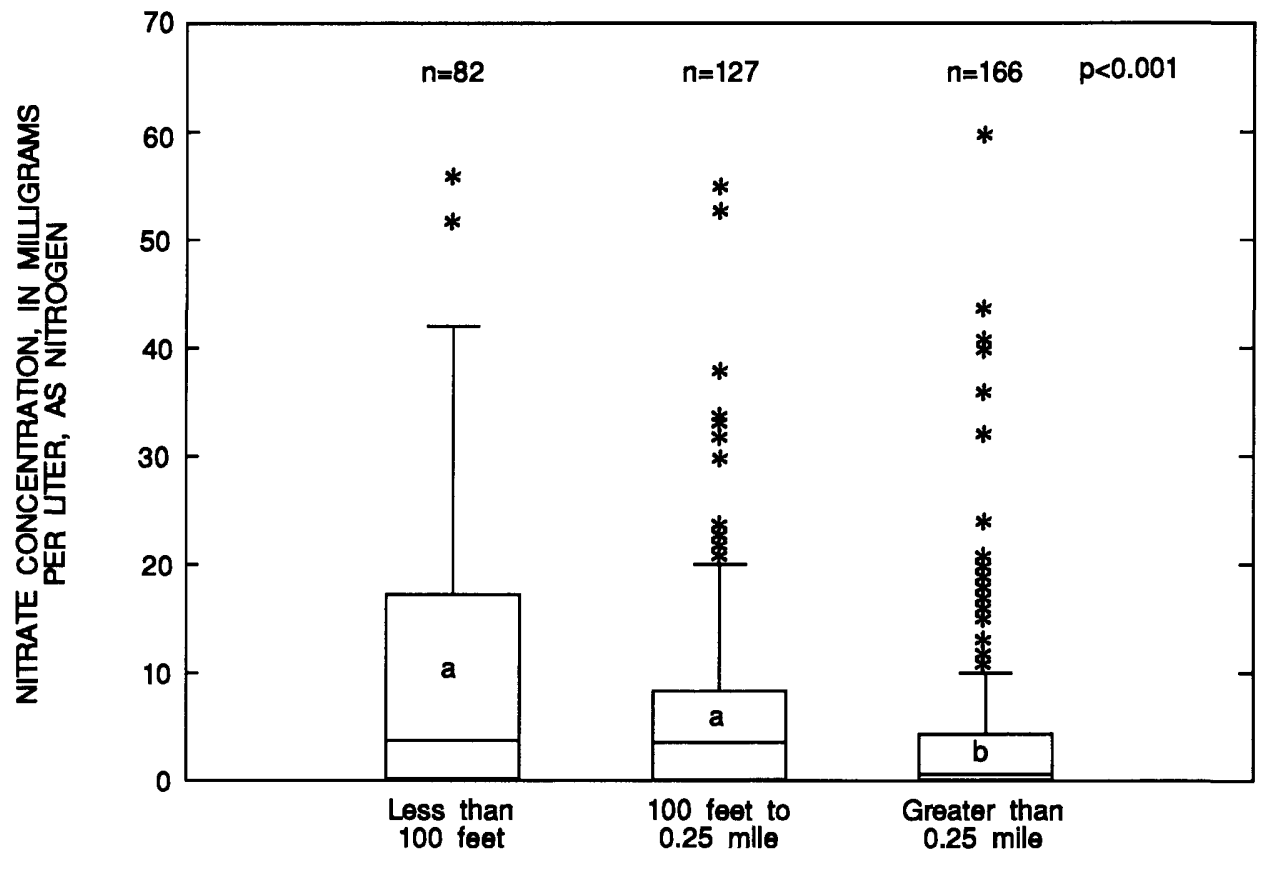

WELL DISTANCE FROM A FEEDLOT

Figure 9. Nitrate concentrations for various well distances from a feedlot [boxplots with letters indicate that a significant difference exists between categories (Tukey's test; $\alpha=0.05$ ); $p$, attained significance level from Kruskal-Wallis test; $n$, number of samples]. 
were located more than $0.25 \mathrm{mi}$ from a feedlot had the lowest median concentration of $\mathrm{NO}_{3}(0.6 \mathrm{mg} / \mathrm{L})$.

Animal manure can be a substantial source of $\mathrm{NO}_{3}$ to ground water (Madison and Brunett, 1985).

Nitrogen isotope ratios can be useful in identifying sources of $\mathrm{NO}_{3}$. Nitrogen isotope data from selected wells in west-central Missouri (Wilkison, 1993) indicate that animal wastes are the predominant source of $\mathrm{NO}_{3}$ in ground water of that area.

\section{Well Distance from a Septic System}

Well distance from a septic system, another possible source of $\mathrm{NO}_{3}$, did not significantly affect $\mathrm{NO}_{3}$ concentrations (Kruskal-Wallis test; $\mathrm{p}=0.128$; fig. 10). Median concentrations were similar in water samples from wells at all three distances from a septic system (Tukey's test; $\alpha=0.05 ; 3.2 \mathrm{mg} / \mathrm{L}$, wells less than 100 $\mathrm{ft} ; 2.1 \mathrm{mg} / \mathrm{L}$, wells between $100 \mathrm{ft}$ and $0.25 \mathrm{mi}$; and $2.05 \mathrm{mg} / \mathrm{L}$, wells more than $0.25 \mathrm{mi}$ from a septic system; fig. 10).

\section{Well Distance from a Chemical Mixing Area}

Nitrate concentrations were significantly related to the distance of a well from a chemical mixing area
(Kruskal-Wallis test; $\mathrm{p}=0.049$; fig. 11), although this relation was not as strong as the one for well distance from a feedlot. Chemical mixing area referred to an area where any kind of agricultural chemical, either fertilizer or pesticide, was mixed. Significant differences were detected between samples from wells with a mixing area less than $100 \mathrm{ft}$ and from wells with a mixing area greater than $0.25 \mathrm{mi}$ away (Tukey's test; $\alpha=0.05$ ). This relation may result from the fact that, where a chemical mixing area was within $100 \mathrm{ft}$ of the well, there was a higher frequency ( 1.7 times) of a feedlot within $100 \mathrm{ft}$ of the well.

\section{Percentage of Row Crops Within a 0.25-Mile Radius of the Well}

Nitrate concentrations were not significantly related to the percentage of row crops within a 0.25 -mi radius of the well (Kruskal-Wallis test; $\mathrm{p}=0.897$; fig. 12). The median $\mathrm{NO}_{3}$ concentration was $1.3 \mathrm{mg} / \mathrm{L}$ in samples from wells that had less than 25 percent in row crops, $1.9 \mathrm{mg} / \mathrm{L}$ for wells with between 26 and 50 percent in row crops, $1.6 \mathrm{mg} / \mathrm{L}$ for wells with between 51 and 75 percent in row crops, and $1.4 \mathrm{mg} / \mathrm{L}$ for wells with greater than 75 percent in row crops within a 0.25 -mi radius of the well. This result would not be

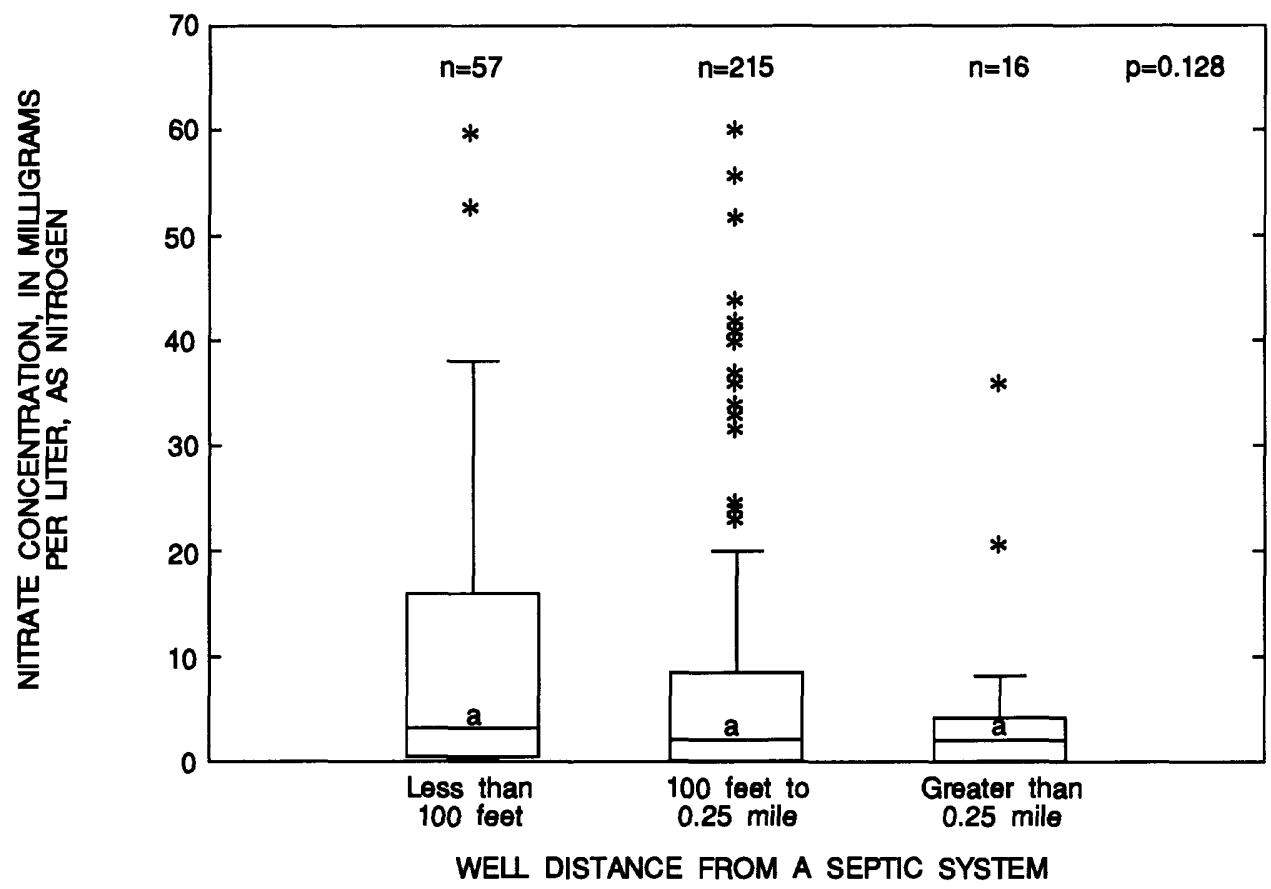

Figure 10. Nitrate concentrations for various well distances from a septic system [boxplots with different letters indicate that a significant difference exists between categories (Tukey's test; $\alpha=0.05$ ); $p$, attained significance level from Kruskal-Wallis test; $n$, number of samples]. 


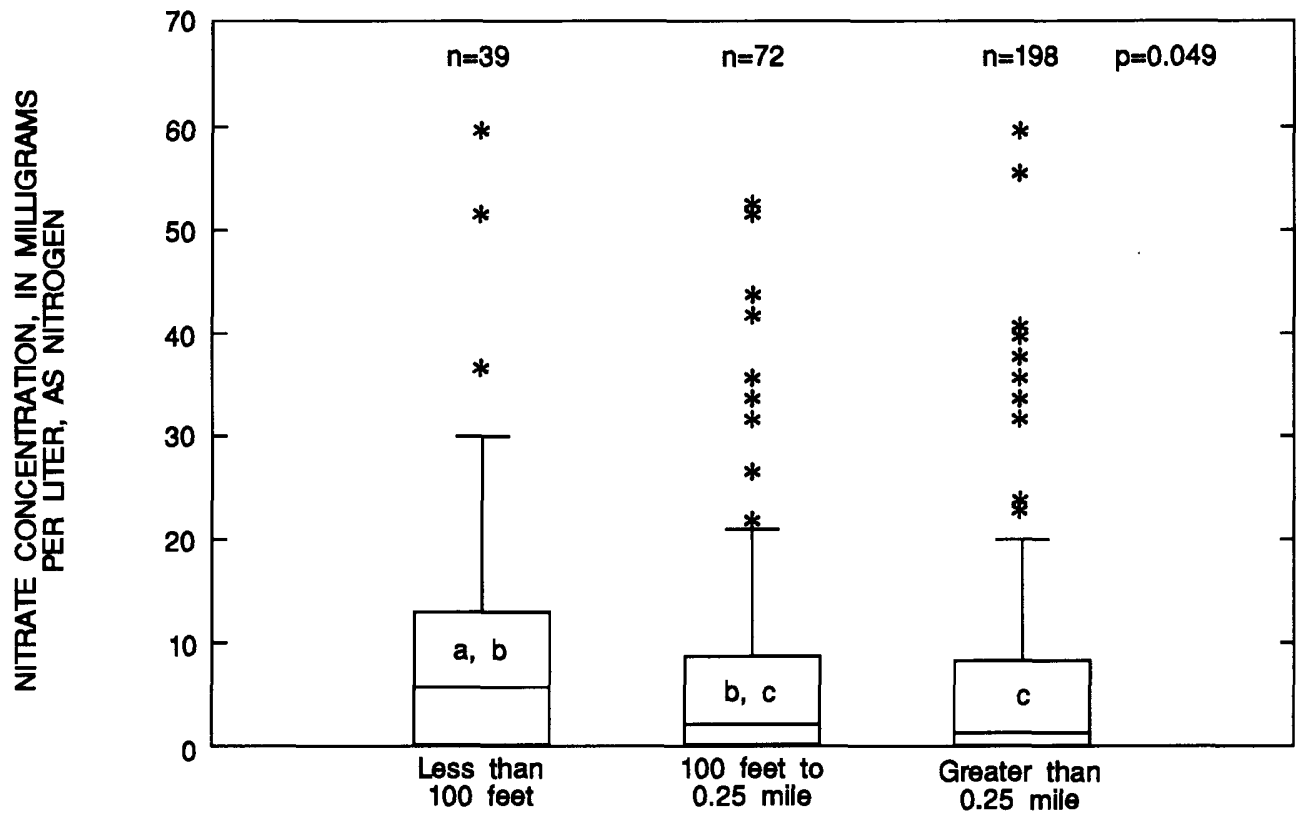

WEL DISTANCE FROM CHEMICAL MIXING AREA

Figure 11. Nitrate concentrations for various well distances from a chemical mixing area [boxplots with different letters indicate that a significant difference exists between categories (Tukey's test; $\alpha=0.05$ ); $p$, attained significance level from Kruskal-Wallis test; $\mathrm{n}$, number of samples].

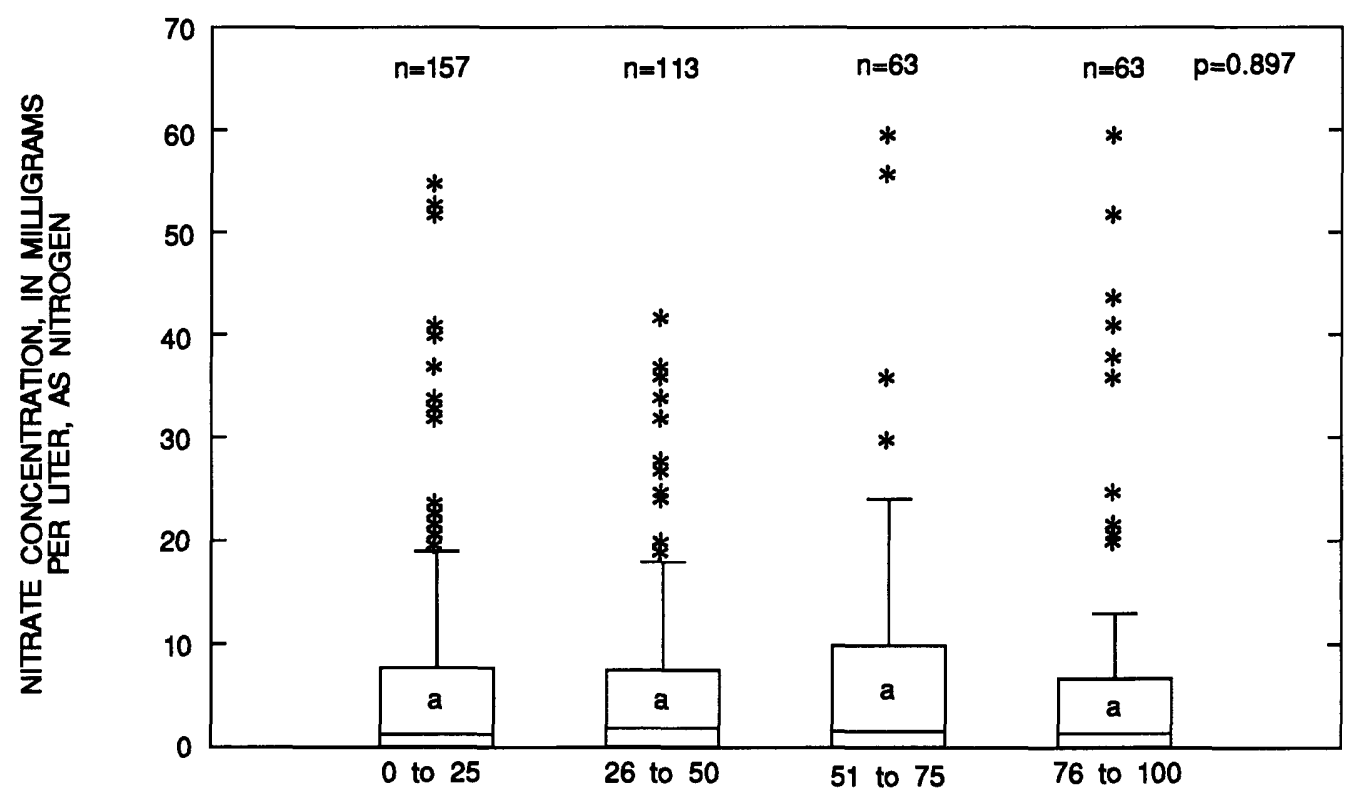

PERCENTAGE OF ROW CROPS WITHIN A 0.25-MILE RADIUS OF A WEL

Figure 12. Nitrate concentrations for various percentages of row crops within a 0.25 -mile radius of a well [boxplots with different letters indicate that a significant difference exists between categories (Tukey's test; $\alpha=0.05$ ); $p$, attained significance level from Kruskal-Wallis test; $n$, number of samples]. 
expected if the widespread application of fertilizers and subsequent leaching to ground water were a major cause of elevated $\mathrm{NO}_{3}$ concentrations. Other research (Blevins and others, 1996) has shown that as much as $8.6 \mathrm{mg} / \mathrm{L}$ of $\mathrm{NO}_{3}$ can enter the ground water from a single fertilizer application. However, it may take several years of repeated applications for the cumulative effects to have a discernible effect on ground water.

\section{Fertilizer Use}

Nitrate concentrations were inversely related to fertilizer use by county (Kruskal-Wallis test; $p<0.001$; fig. 13). Sites with the lowest $\mathrm{NO}_{3}$ concentrations (less than the detection limit of $0.05 \mathrm{mg} / \mathrm{L}$ ) generally were in counties that had the highest fertilizer use [median value of $17,850 \mathrm{lb} / \mathrm{mi}^{2}$ (pounds per square mile)]. Sites with the highest $\mathrm{NO}_{3}$ concentrations (greater than 10 $\mathrm{mg} / \mathrm{L}$ ) were in counties that had the lowest fertilizer use (median value of $6,030 \mathrm{lb} / \mathrm{mi}^{2}$ ) - a relation that was not expected. Estimates of county-wide fertilizer use may not accurately reflect fertilizer rates near the well. Counties with the highest row-crop production (therefore, the highest fertilizer use) generally are in areas of the State that are underlain by alluvial aquifers. Ground water in these areas tends to have lower
$\mathrm{NO}_{3}$ concentrations, possibly because lower dissolved oxygen concentrations produce higher rates of denitrification.

Counties that had the lowest amount of fertilizer use per square mile generally are counties that had the highest livestock production. These counties have soils that often do not fully support row crops and, therefore, many farm operations in these counties include livestock production. County livestock cash receipts for 1990 were used as a surrogate measure of the total amount of livestock within a given county (Reddick, 1992). Elevated $\mathrm{NO}_{3}$ concentrations were significantly related to higher levels of livestock activity (Kruskal-Wallis test; $p<0.001$; fig. 14). These findings are consistent with the significant relation with well proximity to feedlot.

\section{PESTICIDE RESULTS AND FACTORS RELATED TO THEIR OCCURRENCE}

Pesticide analyses from 849 wells and 38 springs were used in this study. One or more pesticides were detected at 101 sites (11.4 percent) at concentrations exceeding $0.1 \mu \mathrm{g} / \mathrm{L}$. Atrazine, the most frequently detected pesticide, was detected at 81 sites.

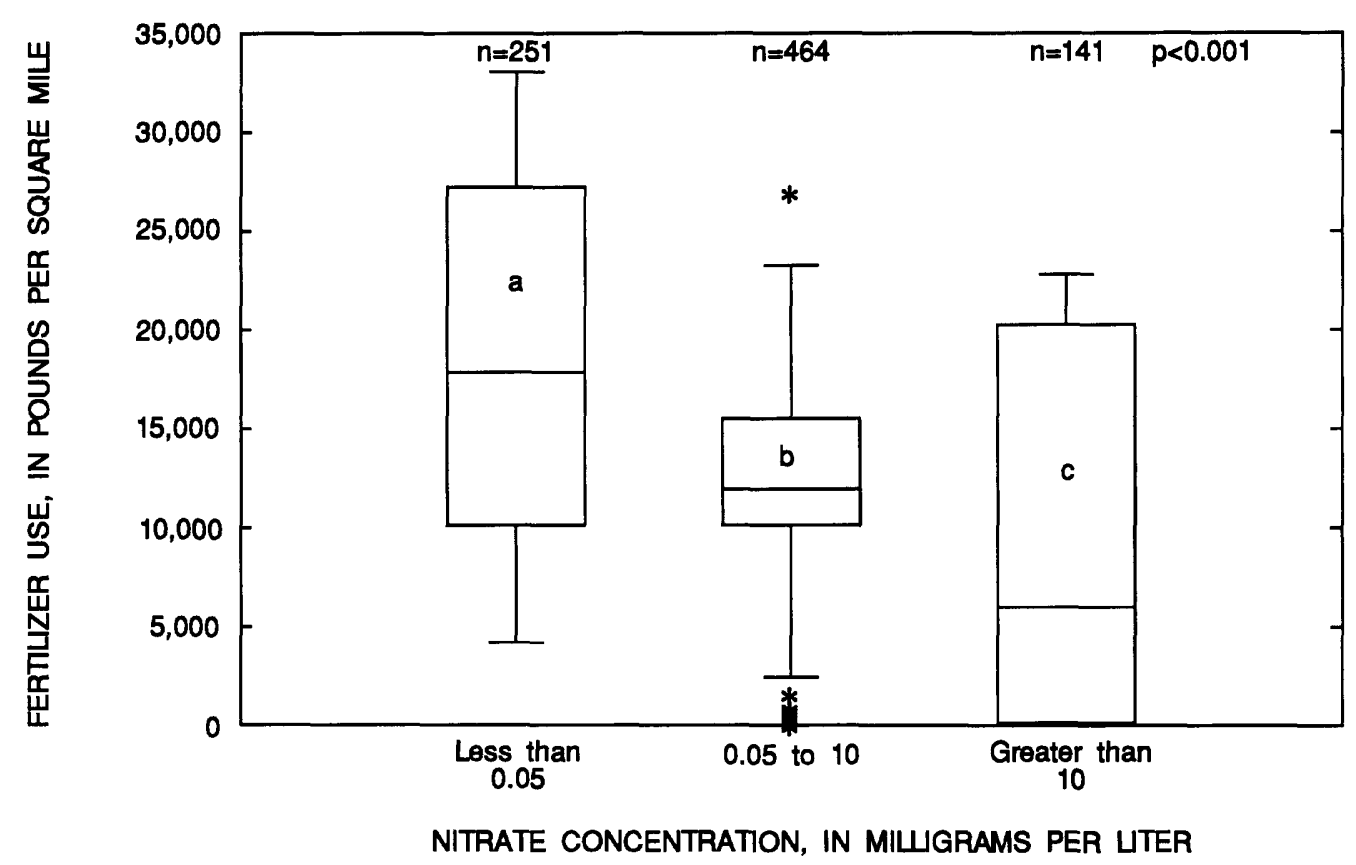

Figure 13. Fertilizer use for various ranges of nitrate concentrations [boxplots with different letters indicate that a significant difference exists between categories (Tukey's test; $\alpha=0.05)$; $p$, attained level of significance from Kruskal-Wallis test; $n$, number of samples]. 


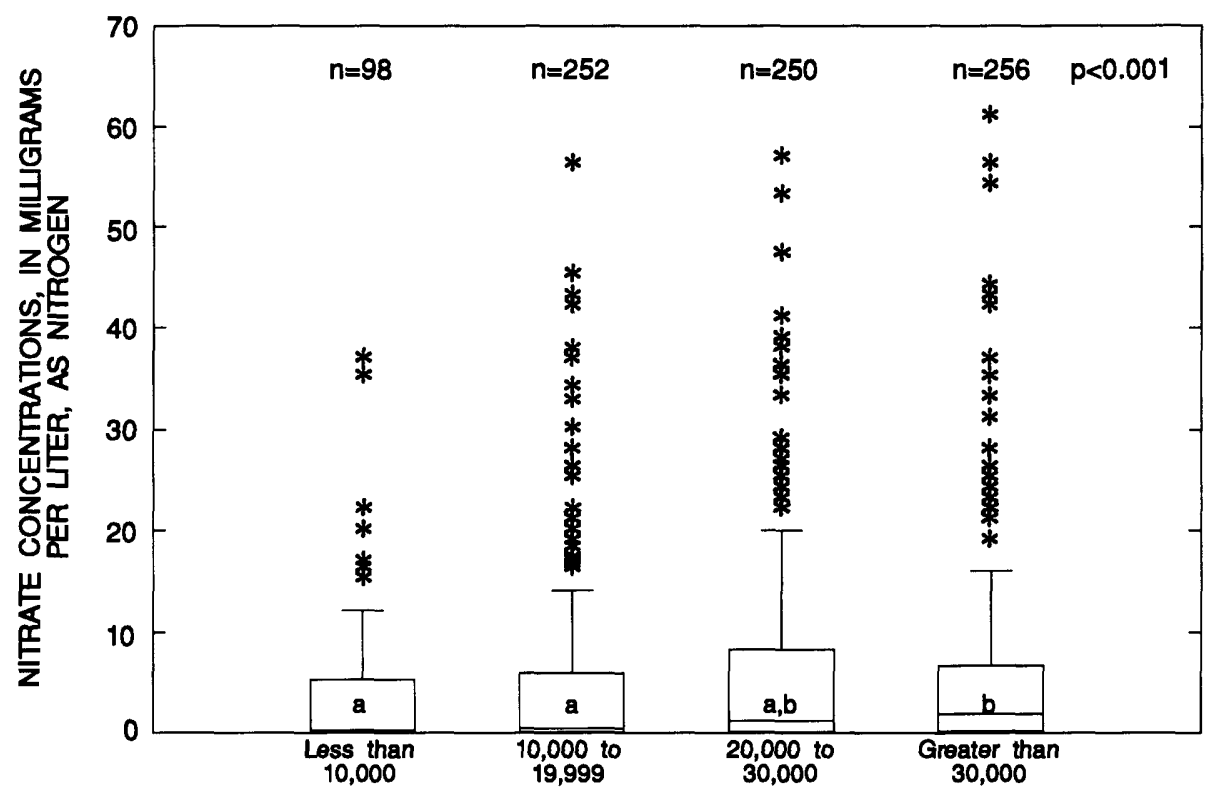

COUNTY LIVESTOCK CASH RECEIPTS, IN THOUSANDS OF DOUARS

Figure 14. Nitrate concentrations related to 1990 county livestock cash receipts [box with different letters indicate that a significant difference exits between categories (Tukey's test; $\alpha=0.05$ ); $p$, attained level of significance from Kruskal-Wallis test; $n$, number of samples].

The order of frequency of pesticide detections was atrazine (9.1 percent), alachlor (3.3 percent), desethylatrazine ( 2.3 percent), metribuzin (1.9 percent), metolachlor (1.5 percent), deisopropylatrazine (1.1 percent), and cyanazine (1.0 percent). Desethylatrazine is a metabolite of atrazine and propazine. Deisopropylatrazine is a metabolite of atrazine, cyanazine, and simazine. Pesticide concentrations exceeded the maximum contaminant level (MCL) or health advisory limit (HAL) for drinking water (U.S. Environmental Protection Agency, 1986) at 17 sites (1.9 percent). Eleven sites exceeded the MCL for atrazine; one site exceeded the MCL for alachlor. The HAL for cyanazine and metolachlor was exceeded at one site each.

Pesticide data were analyzed for statistical relations among hydrogeologic, well, agricultural-practices, and land-use data. The data indicate that water samples from shallow, large-diameter wells completed in glacial drift or Pennsylvanian rocks are most likely to have detectable pesticide concentrations. Additionally, wells where the water table was within $100 \mathrm{ft}$ of the land surface or that had chemicals mixed within $100 \mathrm{ft}$ of the well also were more likely to have detectable pesticide concentrations. Pesticide detections were not significantly related to the percentage of row crops within a 0.25 -mi radius of the well, nor were they related to the county-wide herbicide use.

\section{Aquifer}

Pesticide detection frequency was significantly related to the aquifer in which the well was completed (contingency table test; $\mathrm{p}<0.001$ ). Wells completed in Pennsylvanian rocks had the highest detection percentage ( 22.2 percent), followed by wells completed in glacial drift (15.4 percent). Samples from wells completed in Mississippian/Springfield Plateau (5.2 percent) and Cambrian-Ordovician/Ozark (2.4 percent) aquifers had lower detection frequencies (fig. 15). Wells completed in glacial drift and Pennsylvanian rocks were shallower (Tukey's test; $\alpha=0.05$ ) than those completed in Mississippian/Springfield Plateau or Cambrian-Ordovician/Ozark aquifers because of the depth of the rocks within the State. Shorter flow paths in the glacial drift and Pennsylvanian rocks may result in less time for processes such as degradation, dispersion, adsorption, and transport to occur as pesticides move from the land surface to the ground water. 


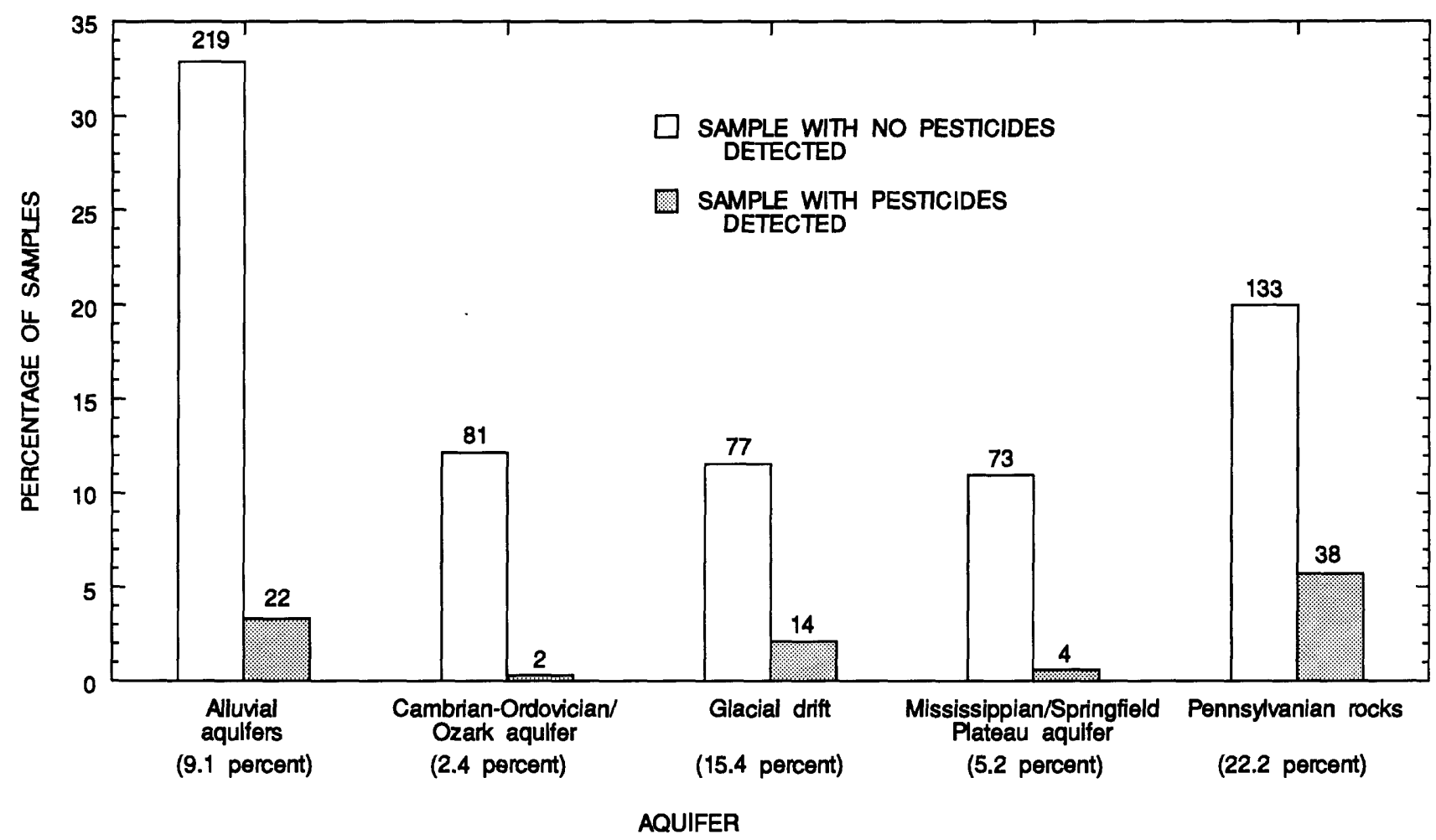

Figure 15. Relation of pesticide detection frequency to aquifer (total number of samples in category above bar; percentage of samples in category with pesticide detections in parentheses below bar).

\section{Well Depth}

Pesticide detection frequency was significantly related to well depth (contingency table test; $p<0.001$ ). The median well depth for samples without pesticide detections was $50 \mathrm{ft}$ as compared to a 30 -ft well depth for samples that had pesticide detections. More than 80 percent of pesticide detections were in samples from wells less than $50 \mathrm{ft}$ deep, and the percentage of detection decreased with increasing well depth (fig. 16).

\section{Well Diameter}

Pesticide detection frequency is significantly related to the well diameter (contingency table test; $\mathrm{p}<0.001$ ). Median well diameter for wells that had no pesticides detected in water samples was 8 in.; median well diameter was 36 in. for wells that had pesticide detections in water samples. This relation to well diameter (fig. 17) may be related to two factors. Largediameter wells more often are completed in either glacial drift or Pennsylvanian rocks, where the depth to water typically is shallower than in other aquifers (with the exception of alluvial aquifers). Therefore, shorter flow paths exist where the large-diameter wells occur. Large-diameter wells also may be more susceptible to near-surface contamination because many of the wells are poorly cased with rocks, bricks, or tiles and were constructed before the implementation of well construction guidelines established in 1987 (Missouri Department of Natural Resources, 1993).

\section{Water-Level Depth Below Land Surface}

Pesticide detection frequency was significantly related to the water-level depth below the land surface (contingency table test; $\mathrm{p}<0.001$ ). The median depth to water for wells with pesticide detections in water samples was $13.4 \mathrm{ft}$, but was $40.8 \mathrm{ft}$ for wells that did not have pesticide detections in water samples. Samples from wells with water levels less than $10 \mathrm{ft}$ deep were about 2.5 times as likely to have pesticide detections as samples from wells where the water level was deeper than $25 \mathrm{ft}$ (fig. 18). Where the water table is near the land surface, shorter flow paths may exist.

\section{Well Distance from a Chemical Mixing Area}

Pesticide detection frequency was significantly related to the well distance from a chemical mixing 


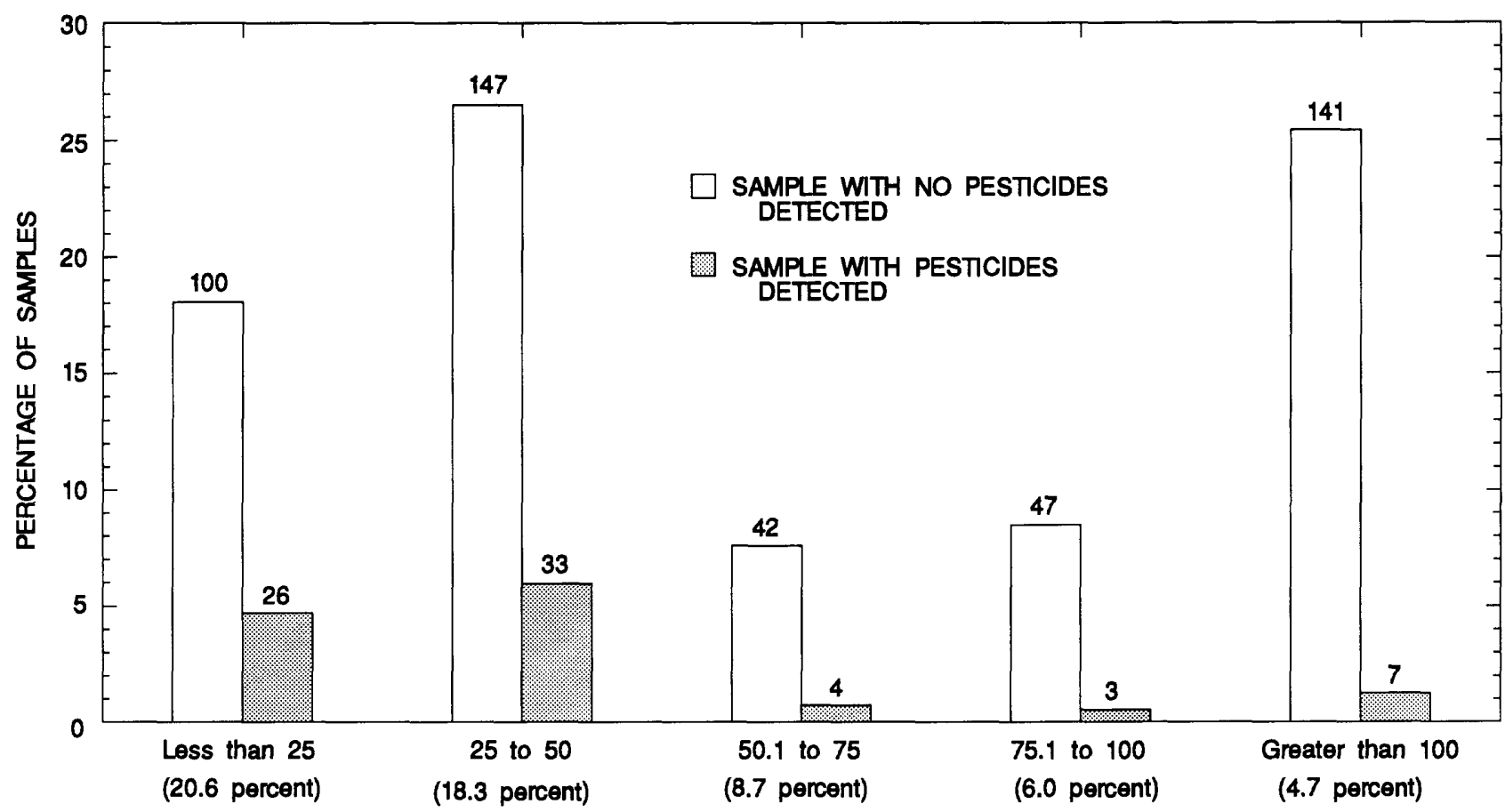

WEL DEPTH, IN FEET

Figure 16. Relation of pesticide detection frequency to well depth (total number of samples in category above bar; percentage of samples in category with pesticide detections in parentheses below bar).

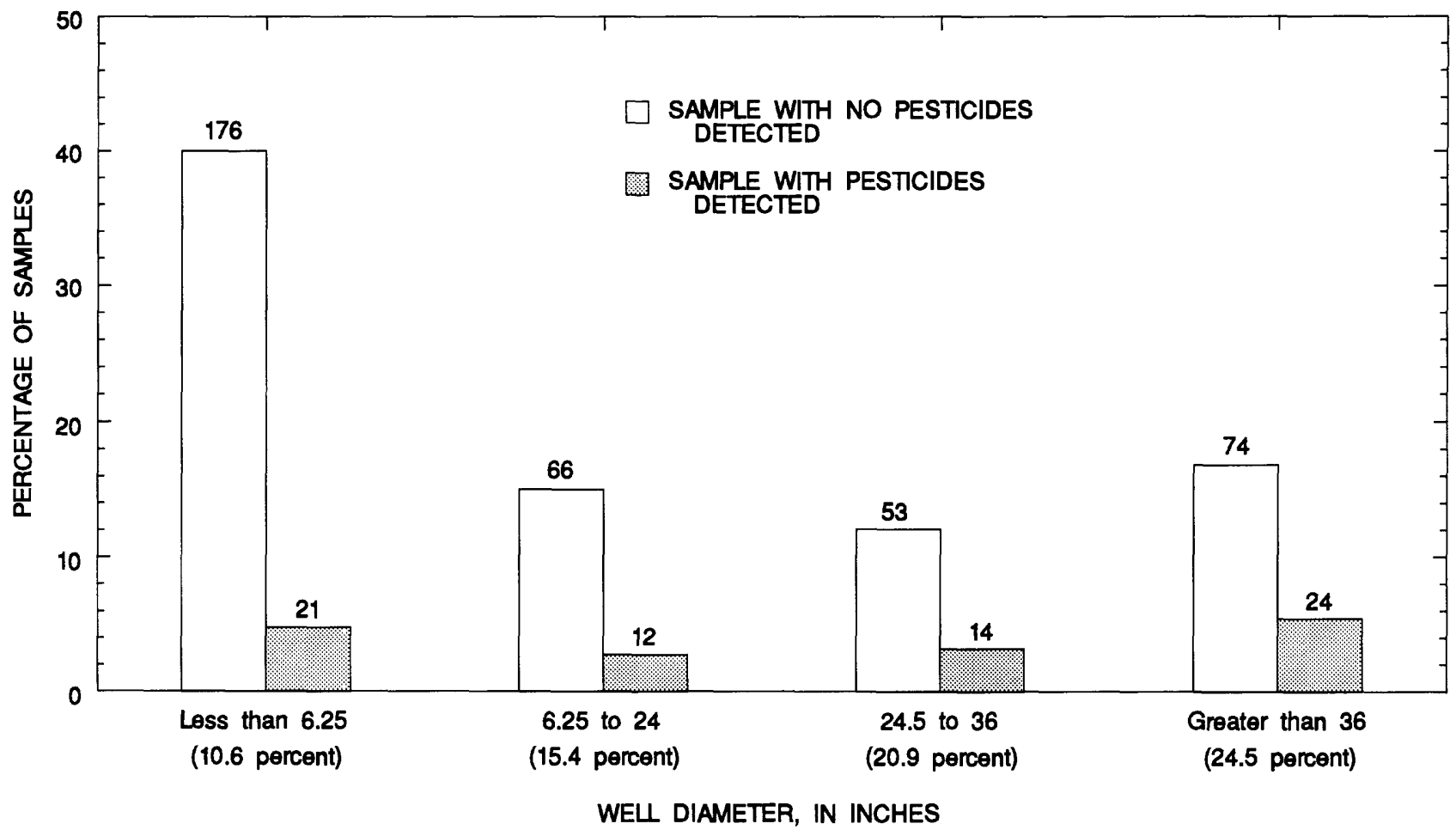

Figure 17. Relation of pesticide detection frequency to well diameter (total number of samples in category above bar; percentage of samples in category with pesticide detections in parentheses below bar). 


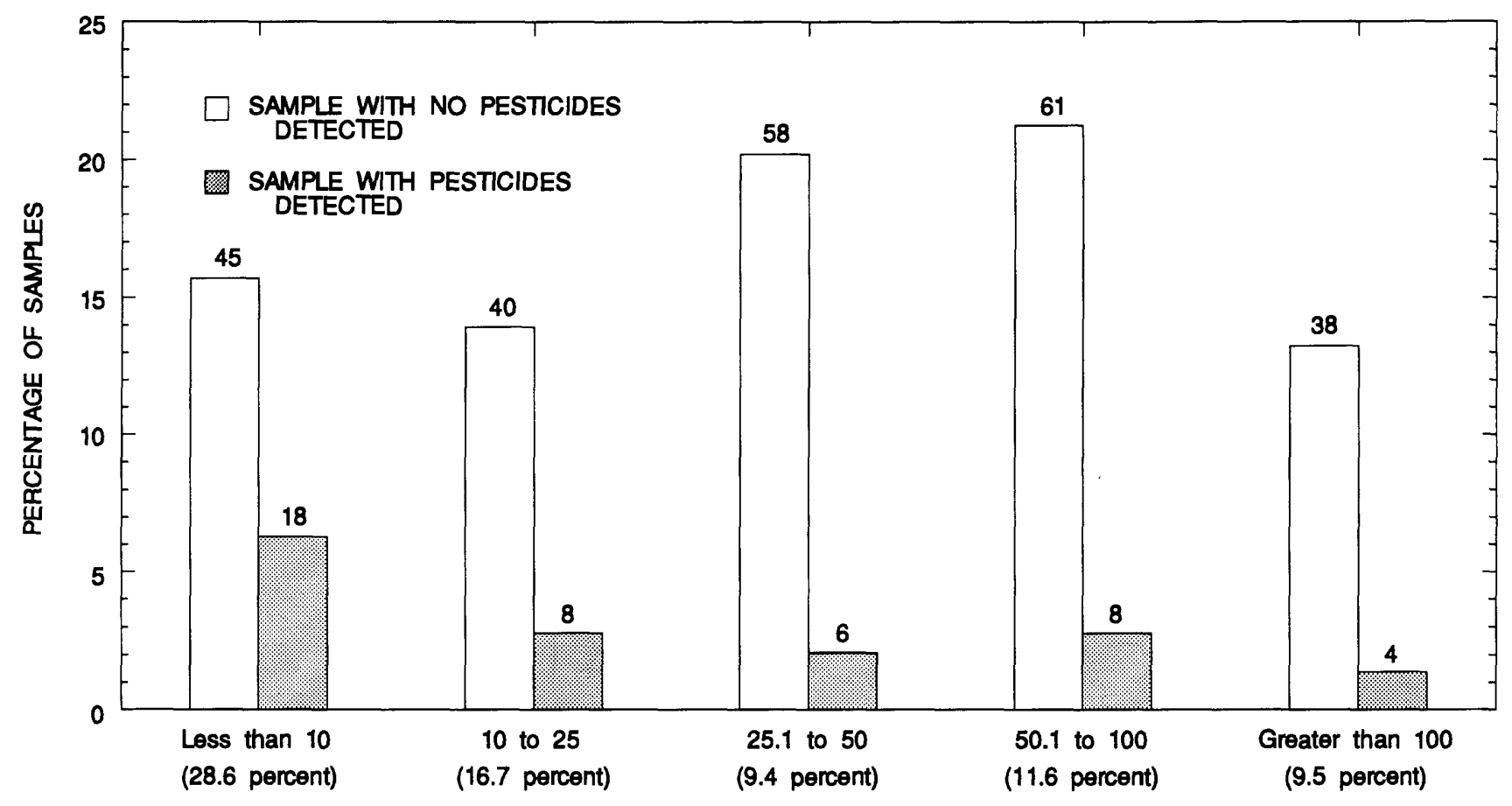

WATER-LEVEL DEPTH BELOW LAND SURFACE, IN FEET

Figure 18. Relation of pesticide detection frequency to water-level depth below land surface (total number of samples in category above bar; percentage of samples in category with pesticide detections in parentheses below bar).

area (contingency table test; $\mathrm{p}<0.001$ ). Pesticide detections were 3.4 times as likely in water samples from wells where chemicals were mixed within $100 \mathrm{ft}$ from the well than for wells where chemicals were mixed more than $0.25 \mathrm{mi}$ from the well (fig. 19). Although only one chemical handling accident was reported by well owners in this study, the mixing of pesticides close to a wellhead allows for the possible contamination of the well through either accidental spills or back-siphoning.

\section{Percentage of Row Crops Within a 0.25-Mile Radius of the Well}

Wells with detectable concentrations of pesticides in water samples had a higher median percentage of row crops within a $0.25-\mathrm{mi}$ radius of the well (50 percent) as compared to those wells that did not have pesticide detections ( 40 percent), although this relation was not statistically significant (contingency table test; $p=0.664$; fig. 20). Kolpin and others (1994) documented similar results throughout the midcontinental United States. The intensity of row crops around the well would be expected to contribute to the frequency of detections. However, because it did not, wellhead practices (within $100 \mathrm{ft}$ ), such as chemical handling procedures, probably are more important in the frequency of pesticide detections.

\section{Herbicide Use}

Pesticide detection frequency was not significantly related to the amount of county-wide herbicide use. Samples with herbicide detections were from counties that had about the same median amount of pesticides applied per square mile as those that had no pesticides detected (Kruskal-Wallis test; $p=0.275$; fig. 21). Because of the large amount of pesticides applied to crops in the State, this relation was expected to be significant. However, the lack of significance probably is because pesticide detection frequency is strongly related to practices near the wellhead. Also, countywide herbicide-use statistics may not accurately reflect herbicide use rates near the well.

\section{Nitrate Concentrations}

Water samples from wells with detectable pesticide concentrations had significantly higher concentrations of $\mathrm{NO}_{3}$ than did samples from wells where no pesticides were detected (Kruskal-Wallis test; $\mathrm{p}<0.001$; fig. 22). The median concentration of $\mathrm{NO}_{3}$ 


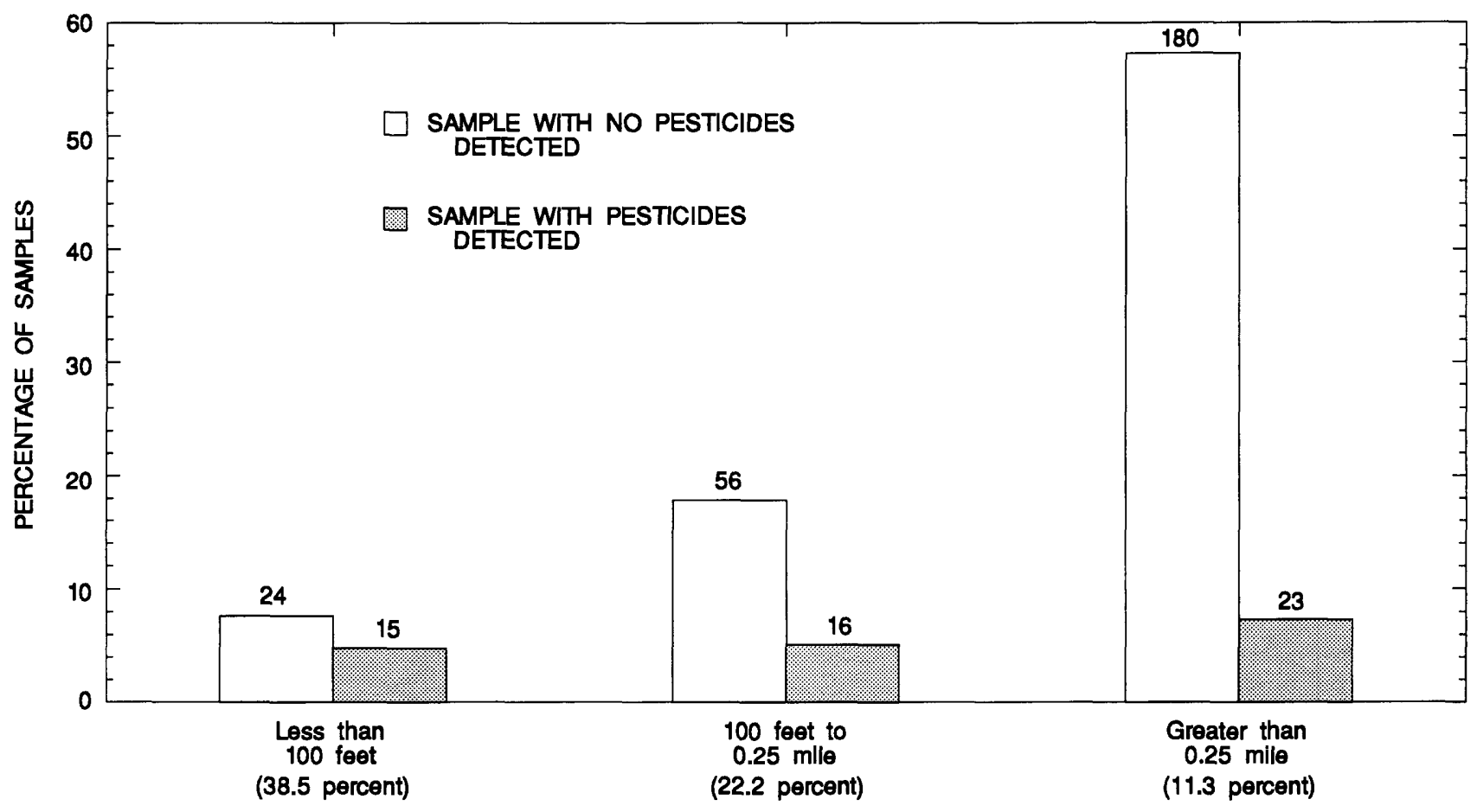

WEL DISTANCE FROM CHEMICAL MIXING AREA

Figure 19. Relation of pesticide detection frequency to well distance from a chemical mixing area (total number of samples in category above bar, percentage of samples in category with pesticide detections in parentheses below bar).

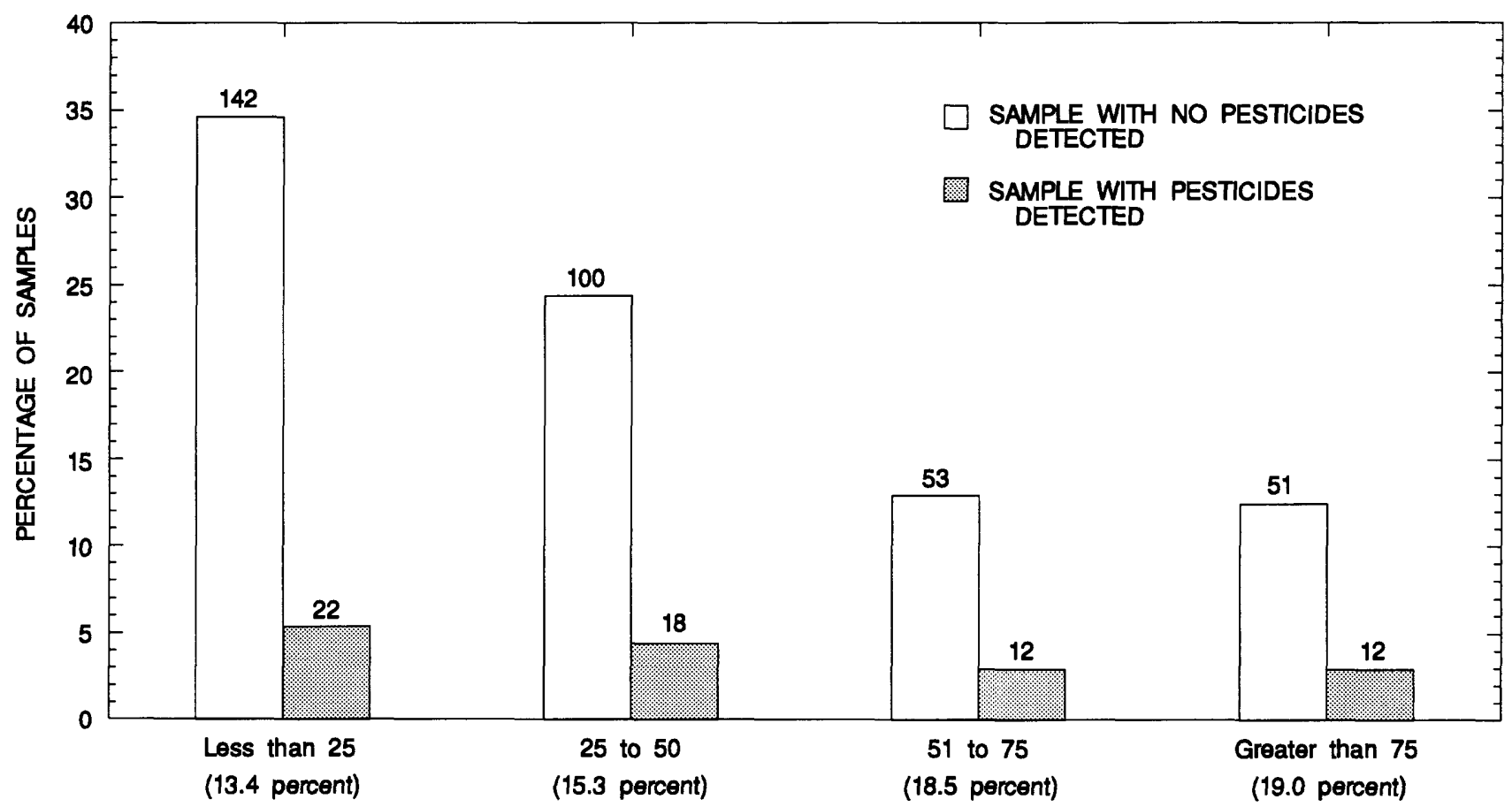

PERCENTAGE OF ROW CROPS WITHIN A 0.25-MILE RADIUS OF A WEL

Figure 20. Relation of pesticide detection frequency to the percentage of row crops within a 0.25 -mile radius of the well (total number of samples in category above bar; percentage of samples in category with pesticides detections in parentheses below bar). 


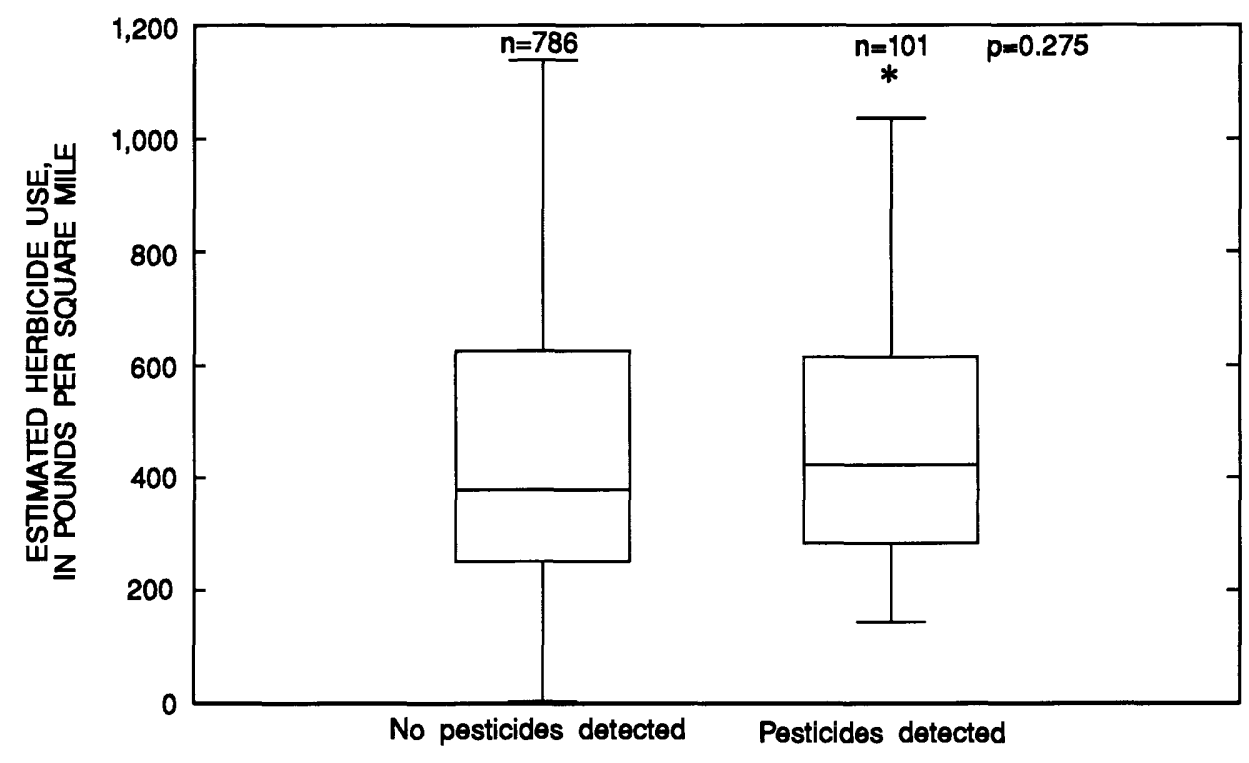

Figure 21. Estimated herbicide use and pesticide detection category ( $p$, attained significance level from Kruskal-Wallis test; $n$, number of samples).

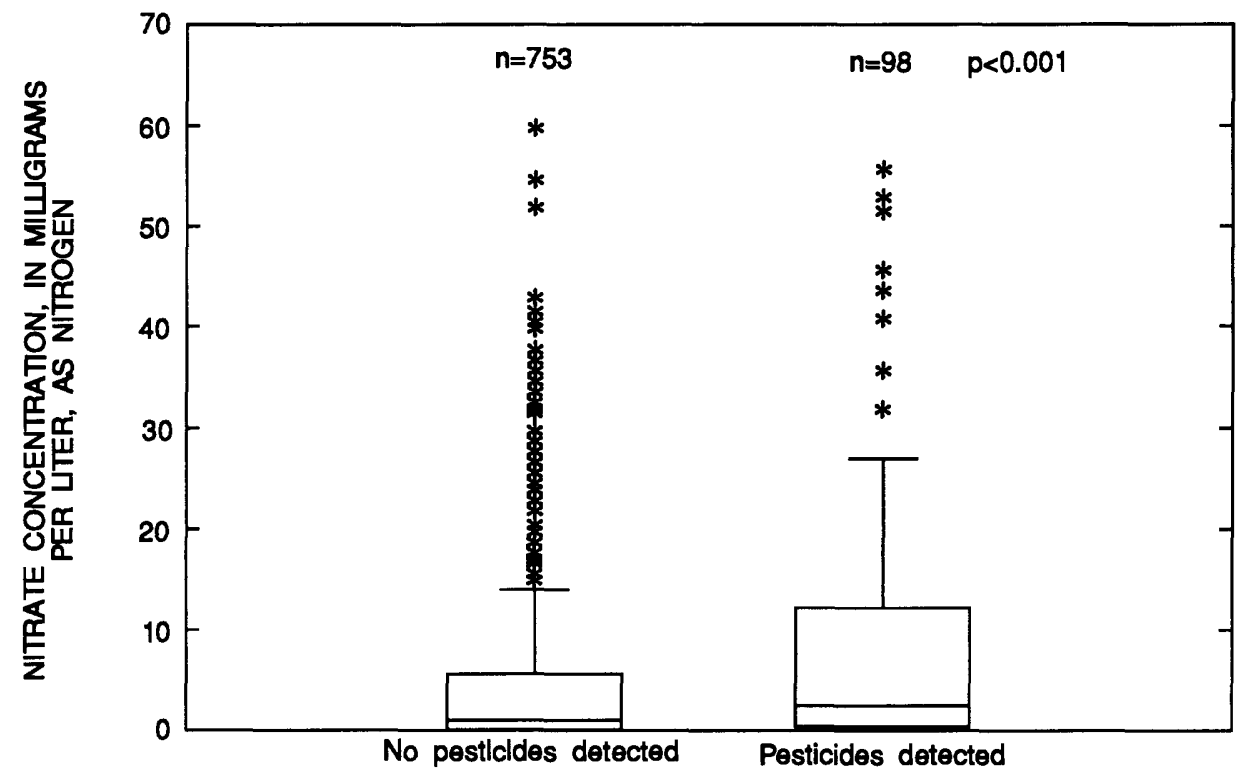

Figure 22. Nitrate concentrations and pesticide detection category ( $p$, attained significance level from Kruskal-Wallis test; $n$, number of samples). 
from samples with pesticides detections was $2.4 \mathrm{mg} / \mathrm{L}$ and was $1.0 \mathrm{mg} / \mathrm{L}$ for samples where no pesticides were detected. This indicates that at least some of the processes and factors that affect transport of $\mathrm{NO}_{3}$ and pesticides are similar. Therefore, areas susceptible to $\mathrm{NO}_{3}$ contamination are susceptible to pesticide contamination as well.

\section{SUMMARY AND CONCLUSIONS}

The occurrence and distribution of nitrate, as nitrogen, and selected pesticides in ground water in Missouri was determined using data collected between 1986 and 1994 from 854 domestic wells and 38 springs. Sampling sites were located in 81 of the 114 counties in Missouri. Hydrogeologic, well, agricultural-practice, and land-use data were used in statistical analyses to determine relations to nitrate concentrations and pesticide detection frequency in ground water.

Nitrate concentrations were detected in ground water much more frequently and at much higher concentrations than were pesticides. More than 36 percent of the sites had nitrate concentrations in excess of 3 milligrams per liter, indicative of a possible anthropogenic source of nitrate for many sites. Almost 18 percent of the sites had nitrate concentrations in excess of the Missouri drinking-water-supply criterion of 10 milligrams per liter.

Elevated nitrate concentrations in ground water were significantly related to aquifer, well depth, well diameter, the water-level depth below the land surface, well distance to a feedlot, and well distance from a chemical mixing area. Ground water from glacial drift or Pennsylvanian rocks had significantly higher concentrations of nitrate than did ground water from alluvial, Mississippian/Springfield Plateau, or CambrianOrdovician/Ozark aquifers. Water samples from wells less than 75 feet deep, greater than 6 inches in diameter, and where the water level was less than 50 feet from the land surface had significantly higher nitrate concentrations than samples from other wells. Water samples from wells less than 0.25 mile from a feedlot and wells where chemicals were mixed within 100 feet of the well had significantly higher nitrate concentrations than samples from other wells.

The frequency of elevated nitrate concentrations (greater than 3 milligrams per liter) in ground water indicates that anthropogenic sources are contributing to the high nitrate concentrations. If the widespread application of fertilizer resulted in elevated nitrate concentrations in ground water, then increases in county fertilizer use and in the percentage of surrounding row crops would be expected to be predictors of increased nitrate concentrations. Neither of these is true. Nitrate concentration is inversely related to county-wide fertilizer use, which indicates that other sources apparently are more important in the transport of nitrate to ground water. Nitrogen-isotope and landuse data indicate that animal wastes were the predominant source of nitrate in ground water in west-central Missouri.

Pesticides were detected in ground water much less frequently than nitrate, and at much lower concentrations. Slightly more than 11 percent of the sites had concentrations of one or more pesticides in excess of 0.1 microgram per liter. Concentrations of at least one pesticide exceeded the maximum contaminant level or health advisory limit in 1.9 percent of samples. Atrazine was the most frequently detected pesticide.

Pesticide detections in ground-water samples were significantly related to aquifer, well depth, well diameter, water-level depth below land surface, well distance to a chemical mixing area, and nitrate concentrations. Wells completed in glacial drift or Pennsylvanian rocks had more frequent pesticide detections than did wells completed in alluvial, Mississippian/Springfield Plateau, or Cambrian-Ordovician/Ozark aquifers. Water samples from wells less than 75 feet deep, greater than 6 inches in diameter, and where the water level was within 50 feet of the land surface were more prone to pesticide detections than samples from other wells. Water samples from wells where chemicals were mixed less than 100 feet from the well were 3.4 times more likely to have a pesticide detection than water from wells where pesticides were mixed at distances greater than 0.25 mile from the well. Ground water in areas susceptible to elevated pesticide concentrations also had significantly higher nitrate concentrations.

This study focused on nitrate and pesticides in samples from domestic wells and shallow ground water in the State. Based on the results of this study, as many as 80,000 domestic wells ( 24 percent) in the State may have nitrate concentrations larger than the drinking-water criterion or have detectable concentrations of one or more pesticides. The data indicate the presence of elevated nitrate and pesticide concentrations in ground water within the State, although they primarily are associated with practices that occur near the wellhead. Results of this study indicate that ele- 
vated nitrate and pesticide concentrations are likely to be localized and limited to shallow ground water. However, continued use of agricultural chemicals could increase the amount of nitrate and pesticides present in ground water, and a state-wide groundwater monitoring network would help to determine the magnitude and extent of contamination and to assess seasonal and historical changes in ground-water quality.

\section{REFERENCES CITED}

Adamski, J.C., and Pugh, A.L., 1996, Occurrence of pesticides in ground water of the Ozark Plateaus Province: Water Resources Bulletin, v. 32, no. 1, p. 97-105.

Anderson, H.W., 1993, Effects of agricultural and residential land use on ground-water quality, Anoka Sand Plain aquifer, east-central Minnesota: U.S. Geological Survey Water-Resources Investigations Report 934074, 62 p.

Battaglin, W.A., Goolsby, D.A., and Coupe, R.H., 1993, Annual use and transport of agricultural chemicals in the Mississippi River, 1991-92, in Selected Papers on Agricultural Chemicals in Water Resources of the Midcontinental United States: U.S. Geological Survey Open-File Report 93-418, p. 26-40.

Blevins, D.W., Wilkison, D.H., Kelly, B.P., and Silva, S.R., 1996, Contribution of fertilizer to nitrate in surface and ground water in claypan soils and glacial till: Journal of Environmental Quality, v. 25, no. 3, p. 584-593.

Brahana, J.V., and Mesko, T.O., 1988, Hydrogeology and preliminary assessment of regional flow in the upper Cretaceous and adjacent aquifers in the northern Mississippi embayment: U.S. Geological Survey WaterResources Investigations Report 87-4000, 65 p.

Cavalier, T.C., Lavy, T.L., and Mattice, J.D., 1989, Assessing Arkansas ground water for pesticides-Methodology and findings: Ground Water Monitoring Review, v. 12 , no. 4, p. 159-166.

Detroy, M.G., Hunt, P.K.B., and Holub, M.A., 1988, Ground-water-quality-monitoring program in IowaNitrate and pesticides in shallow aquifers: U.S. Geological Survey Water-Resources Investigations Report 88-4123, 32 p.

Goetsch, W.D., McKenna, D.P., and Bicki, T.J., 1992, Statewide survey for agricultural chemicals in rural, private water-supply wells in Illinois: Springfield, Illinois Department of Agriculture Bulletin 8522, 4 p.

Goolsby, D.A., and Battaglin, W.A., 1993, Occurrence, distribution and transport of agricultural chemicals in surface waters of the midwestern United States, in Selected Papers on Agricultural Chemicals in Water Resources of the Midcontinental United States: U.S. Geological Survey Open-File Report 93-418, p. 1-25.
Goolsby, D.A., Battaglin, W.A., Fallon, J.D., Aga, D.S., Kolpin, D.W., and Thurman, E.M., 1993a, Persistence of herbicides in selected reservoirs in the midwestern United States-Some preliminary results, in Selected Papers on Agricultural Chemicals in Water Resources of the Midcontinental United States: U.S. Geological Survey Open-File Report 93-418, p. 51-57.

Goolsby, D.A., Thurman, E.M., Pomes, M.L., Myer, M., and Battaglin, W.A., 1993b, Occurrence, deposition, and long range transport of herbicides in precipitation in the midwestern and northeastern United States, in Selected Papers on Agricultural Chemicals in Water Resources of the Midcontinental United States: U.S. Geological Survey Open-File Report 93-418, p. 75-89.

Gormly, J.R., and Spalding, R.F., 1979, Sources and concentrations of nitrate-nitrogen in ground water of the Central Platte Region, Nebraska: Ground Water, v. 17, no. 3, p. 291-301.

Hallberg, G.R., Woida, K., Libra, R.D., Rex, K.D., Sesker, K.D., Kross, B.C., Seigley, L.S., Nations, B.K., Quade, D.J., Bruner, D.R., Nicholson, H.F., Johnson, J.K., and Cherryholmes, K.L., 1992, The Iowa statewide rural well-water survey-Site and well characteristics and water quality: Iowa City, Iowa Department of Natural Resources, Technical Information Series 23, 43 p.

Hanchar, D.W., 1991, Reconnaissance of the occurrence of agricultural chemicals in ground water in Haywood, Lake, Obion, and Shelby Counties, Tennessee: U.S. Geological Survey Water-Resources Investigations Report 90-4064, 28 p.

Hays, P.D., and Morris, E.E., 1993, Transport and fate of pesticides in ground water-Results of the master wells and alluvial aquifer pesticide monitoring programs: Geological Society of America Abstracts with Programs, v. 25, no. 6, p. 92.

Helsel, D.R., and Hirsch, R.M., 1992, Statistical methods in water resources: New York, Elsevier Science Publishing Co., $522 \mathrm{p}$.

Imes, J.L., 1985, The ground-water flow system in northern Missouri with emphasis on the Cambrian-Ordovician aquifer: U.S. Geological Survey Professional Paper $1305,61 \mathrm{p}$.

Imes, J.L., and Emmett, L.F., 1994, Geohydrology of the Ozark Plateaus aquifer system in parts of Missouri, Arkansas, Kansas, and Oklahoma: U.S. Geological Survey Professional Paper 1414-D, $127 \mathrm{p}$.

Klaseus, T.G., Buzicky, G.C., and Schneider, E.C., 1988, Pesticides and groundwater-Surveys of selected Minnesota wells: Minneapolis, Minnesota Department of Health, Legislative Commission on Minnesota Resources, 95 p.

Kolpin, D.W., and Burkart, M.R., 1991, Work plan for regional reconnaissance for selected herbicides and nitrate in ground water of the mid-continental United 
States, 1991: U.S. Geological Survey Open-File Report 91-59, 18 p.

Kolpin, D.W., Burkart, M.R., and Thurman, E.M., 1993, Hydrogeologic, water-quality, and land-use data for the reconnaissance of herbicides and nitrate in near-surface aquifers of the midcontinental United States, 1991: U.S. Geological Survey Open-File Report 93$114,61 \mathrm{p}$.

1994, Herbicides and nitrate in near-surface aquifers in the midcontinental United States, 1991: U.S. Geological Survey Water-Supply Paper 2413, 34 p.

Kolpin, D.W., Goolsby, D.A., and Thurman, E.M., 1995, Pesticides in near-surface aquifers-An assessment using highly sensitive analytical methods and tritium: Journal of Environmental Quality, v. 24, no. 6, p. $1,125-1,132$.

Kolpin, D.W., and Thurman, E.M., 1995, Post-flood occurrence of selected agricultural chemicals and volatile organic compounds in near-surface aquifers in the Upper Mississippi River Basin, 1993, in Floods in the Upper Mississippi River Basin, 1993: U.S. Geological Survey Circular 1120-G, $20 \mathrm{p}$.

Madison, R.J., and Brunett, J.O., 1985, Overview of the occurrence of nitrate in ground water of the United States, in National Water Summary 1984-Hydrologic events, Selected Water-Quality Trends, and GroundWater Resources: U.S. Geological Survey Water-Supply Paper 2275, p. 93-105.

Marikos, Mark, and Skelton, John, 1983, Estimated water use in Missouri, 1980: Rolla, Missouri Division of Geology and Land Survey, 1 sheet.

Mesko, T.O., and Carlson, G.M., 1988, Occurrence of pesticides, nitrate, volatile organic compounds, and trace elements in ground water and streams, southeastern Missouri, 1986-87: U.S. Geological Survey Open-File Report 88-495, 73 p.

Missouri Department of Natural Resources, 1992, Missouri water quality standards-Chapter 7, Water quality: Jefferson City, Clean Water Commission, $100 \mathrm{p}$.

-1993, Missouri private water well, heat pump installation and monitoring well construction rules: Rolla, Missouri Division of Geology and Land Survey, $94 \mathrm{p}$.

Mueller, D.K., Ruddy, B.C., and Battaglin, W.A., 1993, Relation of nitrate concentrations in surface water to land use in the upper-midwestern United States, 198990, in Selected Papers on Agricultural Chemicals in Water Resources of the Midcontinental United States: U.S. Geological Survey Open-File Report 93-418, p. 41-50.

Nations, B.K., and Hallberg, G.R., 1992, Pesticides in Iowa precipitation: Journal of Environmental Quality, v. 21, no. 3, p. 486-492.

Nowell, L.H., and Resek, E.A., 1994, Summary of national standards and guidelines for pesticides in water, bed sediment, and aquatic organisms and their application to water-quality assessments: U.S. Geological Survey Open-File Report 94-44, 115 p.

Pauley, V., ed., 1991, 1991 Missouri farm facts: Columbia, Missouri Agricultural Statistics Service, $68 \mathrm{p}$.

-1993, 1993 Missouri farm facts: Columbia, Missouri Agricultural Statistics Service, 72 p.

Reddick, C., ed., 1992, 1992 Missouri farm facts: Columbia, Missouri Agricultural Statistics Service, 68 p.

Sievers, D.M., and Fulhage, C.D., 1992, Survey of rural wells in Missouri for pesticides and nitrate: Ground Water Monitoring Review, v. 12, no. 4, p. 142-150.

Smith, G.S., and Fairchild, M.L., 1990, Pesticide use survey in Missouri field crops-1989: Columbia, University of Missouri, M-141, $40 \mathrm{p}$.

Spalding, R.F., Burbach, M.E., and Exner, M.E., 1989, Pesticides in Nebraska's ground water: Ground Water Monitoring Review, v. 9, no. 4, p. 126-133.

Spalding, R.F., Gromly, J.R., Curtiss, B.H., and Exner, M.E., 1978, Nonpoint nitrate contamination of ground water in Merrick County, Nebraska: Ground Water, v. 16 , no. 2, p. 86-95.

Steichen, J., Koelliker J., Grosh, D., Heiman, A., Yearout, R., and Robbins, V., 1988, Contamination of farmstead wells by pesticides, volatile organics, and inorganic chemicals in Kansas: Ground Water Monitoring Review, v. 8, no. 3, p. 153-160.

U.S. Department of Agriculture, 1994, Agricultural chemical usage-1993 field crops summary: Washington, D.C., National Agricultural Statistics Service Publication $\mathrm{Ag}$ Ch 1, $114 \mathrm{p}$.

U.S. Department of the Census, 1991, Census of population and housing-1990: Washington, D.C., Government Printing Office Publication CPH-L-80, 345 p.

U.S. Environmental Protection Agency, 1986, Quality criteria for water 1986: U.S. Environmental Protection Agency EPA 440/5-86-001, 453 p.

University of Missouri, 1993, Missouri fertilizer tonnage report-1993: Columbia, Agricultural Experiment Station, $6 \mathrm{p}$.

Walsh, J.F., Wheeler, B.J., Olsen, B.M., and Klaseus, T.G., 1993, Pesticides and their breakdown products in Minnesota groundwater: Minneapolis, Minnesota Department of Health, 83 p.

Wilkison, D.H., 1993, Source and extent of nitrate, atrazine, and related triazine herbicides in shallow wells, westcentral Missouri: Kansas City, University of Missouri, unpublished M.S. thesis, $93 \mathrm{p}$.

Wilkison, D.H., and Maley, R.D., 1994, Occurrence of herbicides, nitrite plus nitrate, and selected trace elements in ground water from northwestern and northeastern Missouri, July 1991 and 1992: U.S. Geological Survey Open-File Report 94-332, 64 p.

Young, H.L., 1992, Hydrogeology of the Cambrian-Ordovician aquifer system in the Northern Midwest, United 
States: U.S. Geological Survey Professional Paper 1405-B, $99 \mathrm{p}$.

Ziegler, A.C., Wallace, W.C., Blevins, D.W., and Maley, R.D., 1993, Occurrence of pesticides, nitrite plus nitrate, arsenic, and iron in water from two reaches of the Missouri River alluvium, northwestern MissouriJuly 1988 and June-July 1989: U.S. Geological Survey Open-File Report 93-101, 30 p.
Ziegler, A.C., Wilkison, D.H., and Maley, R.D., 1994, Occurrence of selected pesticides, nutrients, selected trace elements, and radionuclides in ground and surface water from west-central Missouri-July 1990March 1991: U.S. Geological Survey Open-File Report 93-362, 71 p. 


\section{TABLES}

- PAGE 29 follows - 


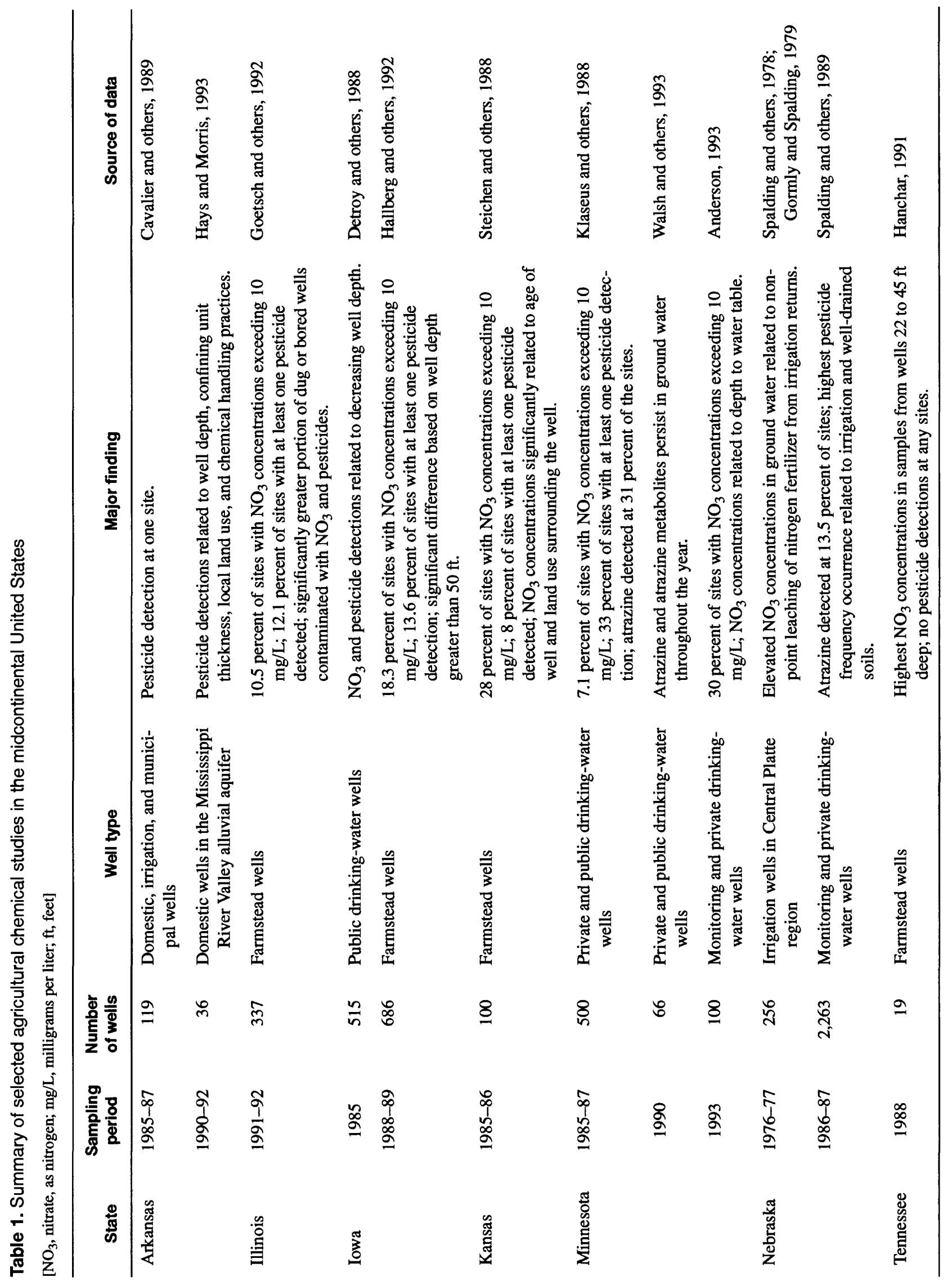




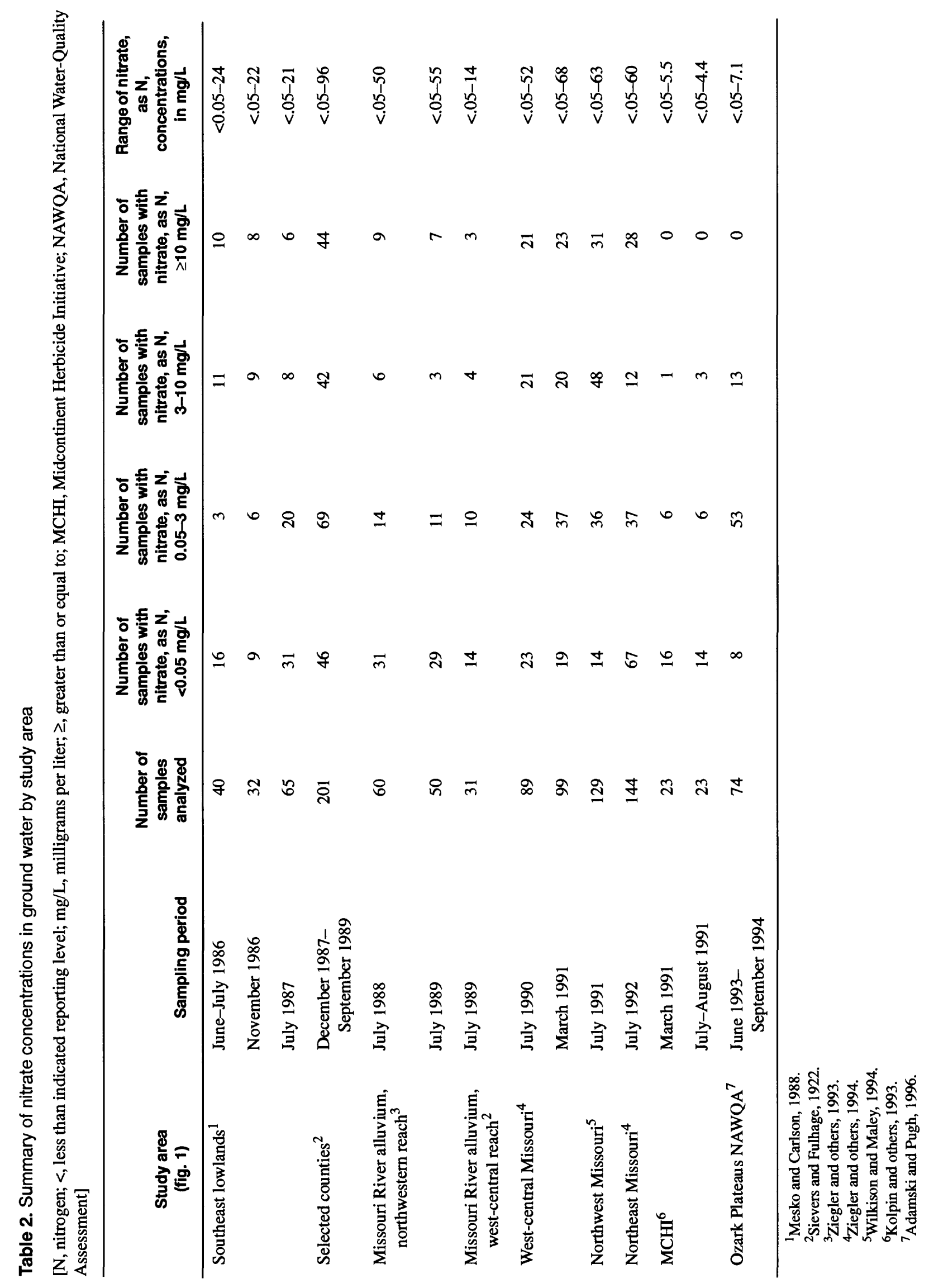




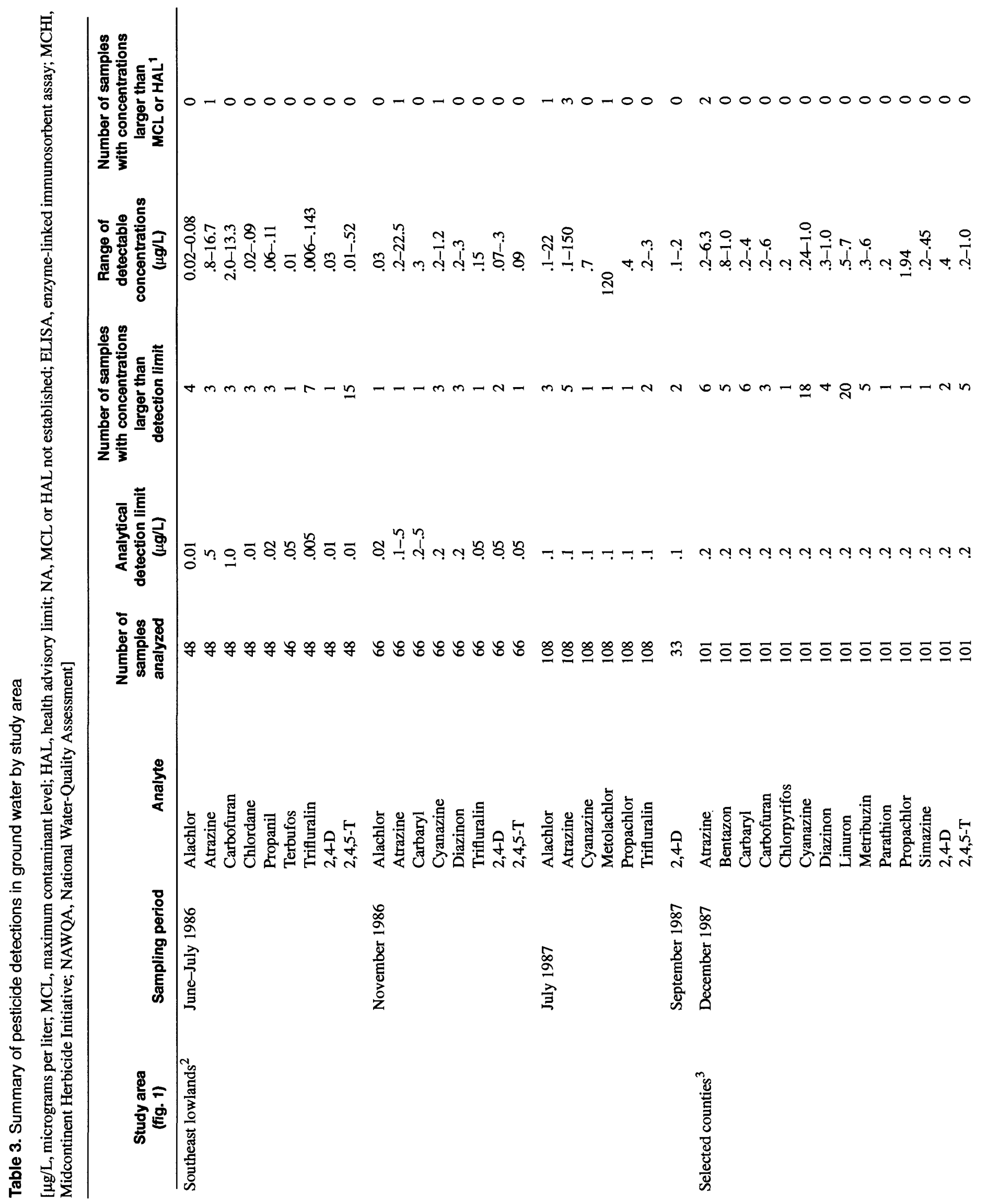




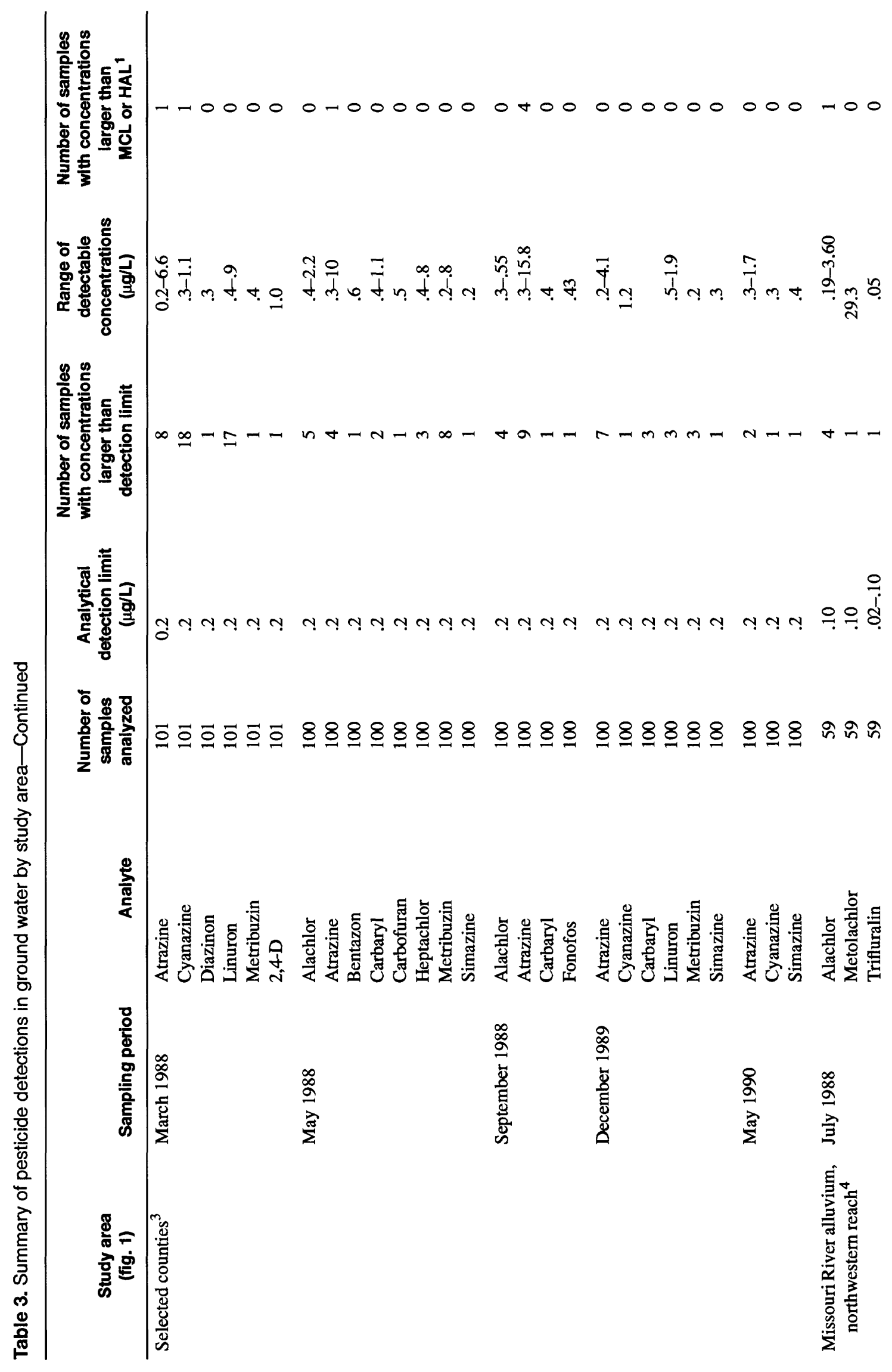




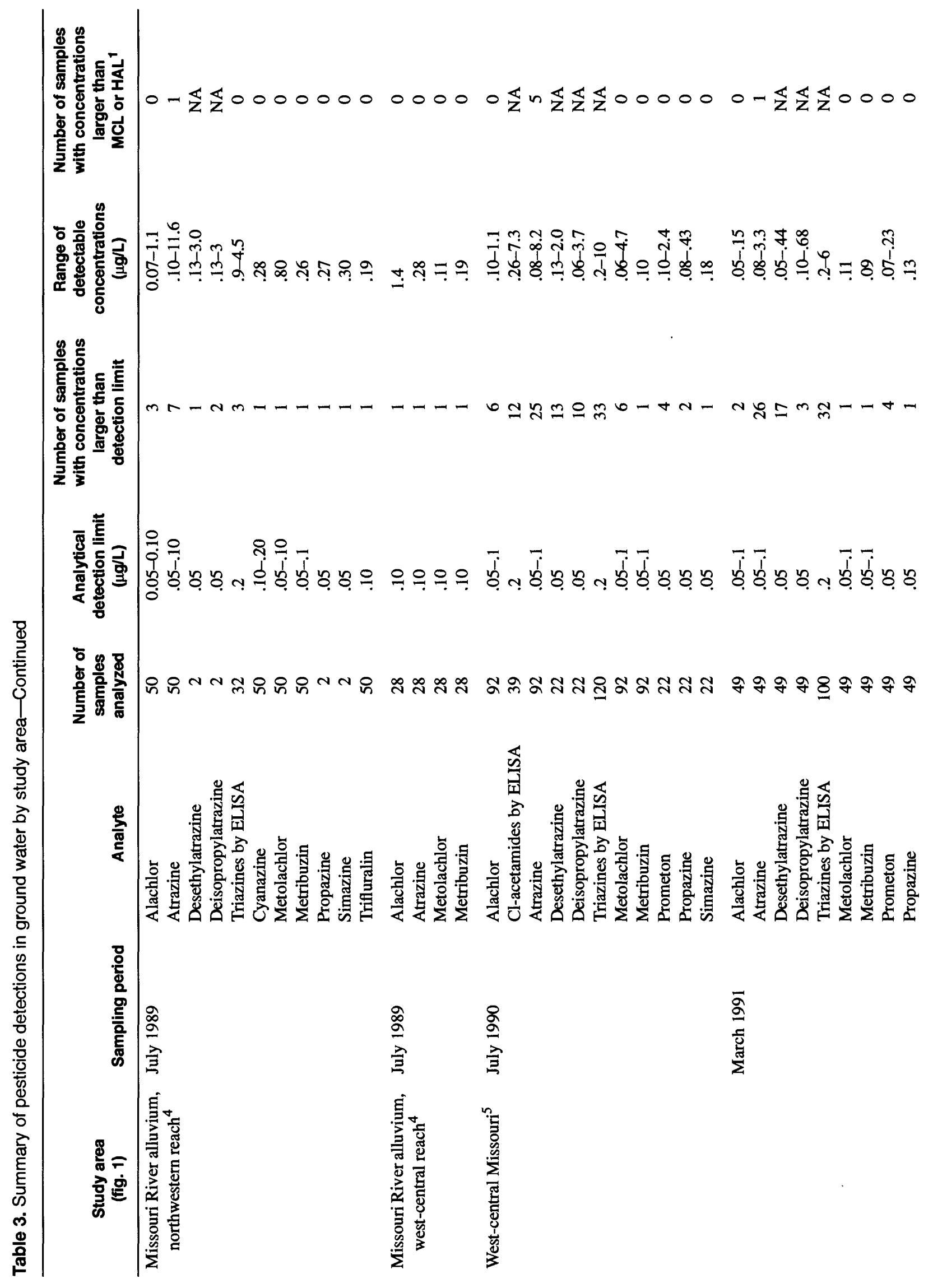




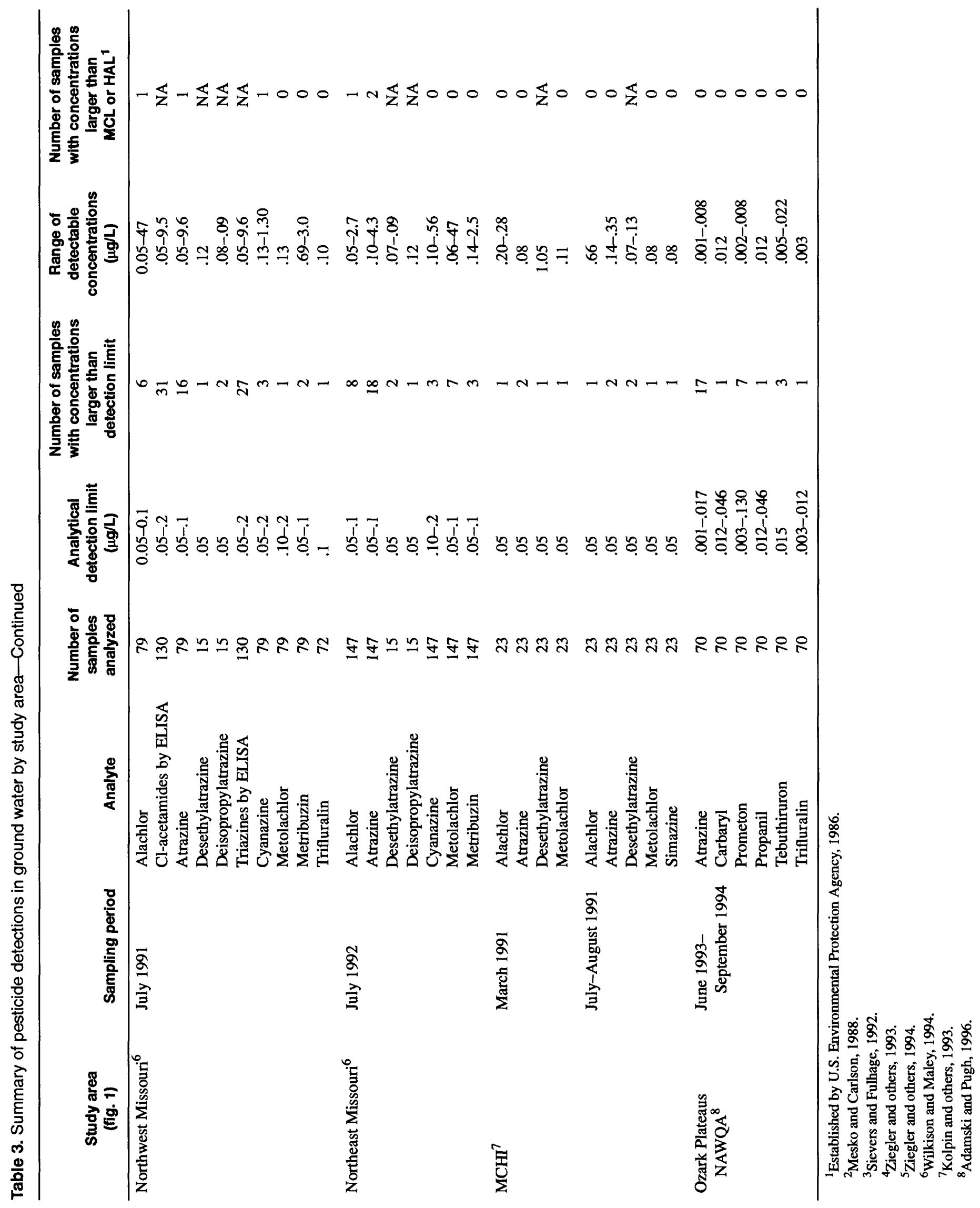

